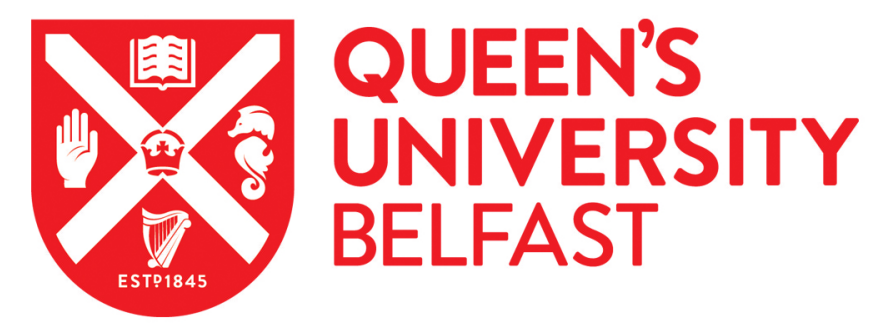

\title{
Trust, Satisfaction and Online Repurchase Intention: The Moderating Role of Perceived Effectiveness of E-commerce Institutional Mechanisms
}

\author{
Fang, Y., Qureshi, I., Sun, H., McCole, P., Ramsey, E., \& Lim, K. H. (2014). Trust, Satisfaction and Online \\ Repurchase Intention: The Moderating Role of Perceived Effectiveness of E-commerce Institutional \\ Mechanisms. MIS Quarterly, 38(2), 407-427. https://doi.org/10.25300/MISQ/2014/38.2.04
}

Published in:

MIS Quarterly

\section{Document Version:}

Peer reviewed version

Queen's University Belfast - Research Portal:

Link to publication record in Queen's University Belfast Research Portal

\begin{abstract}
Publisher rights
Copyright 2014 by the Management Information Systems Research Center (MISRC) of the University of Minnesota. Permission to make digital or hard copies of part or all of this work for personal or classroom use is granted without fee provided that copies are not made or distributed for profit or commercial advantage and that copies bear this notice and full citation on the first page. Copyright for components of this work owned by others than the MISRC must be honored. Abstracting with credit is permitted. To copy otherwise, to post on servers, or to redistribute to lists requires prior specific permission and possibly a fee. Request permission to publish from: MIS Quarterly; Carlson School of Management; University of Minnesota; 321 19th Ave. So.; Minneapolis, MN 55455. ISSN: 0276-7783.

General rights

Copyright for the publications made accessible via the Queen's University Belfast Research Portal is retained by the author(s) and / or other copyright owners and it is a condition of accessing these publications that users recognise and abide by the legal requirements associated with these rights.
\end{abstract}

Take down policy

The Research Portal is Queen's institutional repository that provides access to Queen's research output. Every effort has been made to ensure that content in the Research Portal does not infringe any person's rights, or applicable UK laws. If you discover content in the Research Portal that you believe breaches copyright or violates any law, please contact openaccess@qub.ac.uk. 


\title{
Trust, Satisfaction and Online Repurchase Intention: The Moderating Role of Perceived Effectiveness of E-commerce Institutional Mechanisms
}

\author{
YULIN FANG \\ Department of Information Systems \\ City University of Hong Kong \\ Hong Kong SAR, China \\ Yulin.fang@cityu.edu.hk \\ ISRAR QURESHI \\ Department of Management and Marketing \\ Hong Kong Polytechnic University \\ Hong Kong SAR, China \\ israr.qureshi@polyu.edu.hk \\ HESHAN SUN \\ School of Information Resources and Library Science \\ University of Arizona \\ Arizona, U.S.A \\ hsun@email.arizona.edu \\ PATRICK MCCOLE \\ Queen’s University Management School \\ Queen's University Belfast \\ Northern Ireland, United Kingdom \\ p.mccole@qub.ac.uk

\section{ELAINE RAMSEY} \\ Department of Business, and Enterprise \\ Ulster Business School, University of Ulster \\ Northern Ireland, United Kingdom \\ e.ramsey@ulster.ac.uk \\ KAI H. LIM * \\ Department of Information Systems \\ City University of Hong Kong \\ Hong Kong SAR, China \\ iskl@cityu.edu.hk \\ *: Corresponding author
}

\section{Acknowledgement}

The authors are grateful to the senior editor, the associate editor, and the anonymous reviewers for their invaluable guidance and insightful comments. The work described in this article was supported by grants from City University of Hong Kong (SRG 7002521), The Hong Kong Research Grants Council (Project No. CityU 142512), and Hong Kong Polytechnic University (\# A-PJ58, ICRG-PolyU) 


\section{Author Biographies}

Yulin Fang is an Associate Professor in the Department of Information Systems, City University of Hong Kong. He earned his Ph.D. at Richard Ivey School of Business, University of Western Ontario. His current research is focused on knowledge management and innovation, social media, and e-commerce. He has published papers in journals such as Strategic Management Journal, MIS Quarterly, Information Systems Research, Journal of Management Information Systems, Journal of Management Studies, Organizational Research Methods, Journal of the Association for Information Systems, and others. He has won the 2009 Senior Scholars Best IS Publication Award, and was the Samsung Best Paper Award Finalist and the Carolyn Dexter Award Finalist at the 2008 Academy of Management Conference.

Israr Qureshi is an Assistant Professor at Hong Kong Polytechnic University. He earned his Ph.D. at University of Western Ontario. He is currently involved in various projects that investigate social innovation and social entrepreneurship in China and India. His current projects examine: role of ICT in social inclusion; social entrepreneurship at the base of the pyramid; comparative study of social enterprise sector in China and India. He applies both qualitative and quantitative methods to investigate various issues related to social entrepreneurship. He has published in MIS Quarterly, Journal of Management, Journal of Management Studies, Organizational Research Methods, among others.

Heshan Sun is an assistant professor in the School of Information Resources and Library Science, the University of Arizona. His research interests include human-computer interfaces, three-dimensional technology, user adoption and continued use of technology, e-commerce, social media, and statistics and quantitative methods, among others. His research has been published (or will appear) in top information systems and information science journals such as the MIS Quarterly, Journal of the Association for Information Systems, Journal of the American Society for Information Science and Technology, International Journal of Human-Computer Studies, AIS Transactions on Human-Computer Interaction, and Communications of the Association for Information Systems. Heshan is an associate editor for AIS Transactions on Human-Computer Interaction and serves on the editorial board of Journal of Database Management and IEEE Transactions on Engineering Management. Heshan has been recognized in different bibliometric studies as a top IS researcher. See http://sun.faculty.arizona.edu for more details.

Patrick McCole is a Senior Lecturer in Marketing at Queen’s University Management School, Queen's University Belfast. He received his BA (Hons) and $\mathrm{PhD}$ degrees from the University of Ulster. His main research interests include trust, distrust, e-commerce and online buying behaviour as well as the application of analytics for marketing decision-making. Patrick's work has been published in journals such as European Journal of Information Systems, Information and Management and Journal of Business Research.

Elaine Ramsey is a Senior Lecturer in the department of Business, Retail and Financial Services, University of Ulster (UU). She received her Ph.D. in SME E-Marketing from UU in 2005. Her main research interests relate to the adoption and diffusion of IT among SMEs, and the inherent issues relative to ecommerce deployment. She has published in the European Journal of Information Systems, Journal of Business Research, Journal of Marketing Management, International Journal of Innovation Management, Service Industries Journal, and others.

Kai H. Lim, Professor of Information Systems at City University of Hong Kong. He received his Ph.D. from the University of British Columbia, Canada. His research interests include IT-enabled business strategy and agility, e-Commerce-related adoption issues, human-computer interactions, and crosscultural issues related to information systems management. He is currently serving as a Senior Editor of MISQ and has served on the editorial board of ISR, MISQ, and Journal of the Association for Information Systems (JAIS). 


\title{
Trust, Satisfaction and Online Repurchase Intention: The Moderating Role of Perceived Effectiveness of E-commerce Institutional Mechanisms
}

\begin{abstract}
The effects of e-commerce institutional mechanisms on trust and online purchase have traditionally been understood in the initial online purchase context. This study extends this literature by exploring the role of e-commerce institutional mechanisms in the online repurchase context. In doing so, it responds to the emerging call for understanding the institutional context under which customer trust operates in an e-commerce environment. Specifically, this study introduces a key moderator, perceived effectiveness of e-commerce institutional mechanisms (PEEIM) to the relationships between trust, satisfaction and repurchase intention. Drawing on the theory of organizational trust, and based on a survey across 362 online returning customers, we find that PEEIM negatively moderates the relationship between trust in an online vendor and online customer repurchase intention, as it decreases the importance of trust to promoting repurchase behavior. We also find that PEEIM positively moderates the relationship between customer satisfaction and trust as it enhances the customers' reliance on past transaction experience with the vendor to reevaluate their trust in the vendor. Consistent with the predictions made in the literature, PEEIM does not directly affect trust or repurchase intention. Academic and practical implications and future research directions are discussed.
\end{abstract}

Keywords: E-commerce, trust, online repurchase intention, e-commerce institutional mechanisms, moderation analysis, partial least square modeling 


\section{Introduction}

As online retailing has grown rapidly worldwide and become globally competitive over the past decade, how to retain existing customers to make repeated purchases (hereafter referred to as repurchase) becomes a more important concern for online vendors than ever before (Johnson 2008). In this context, a large number of studies have been conducted to understand what makes online customers repurchase from an online vendor. Amongst the many influencing factors, trust has been found to be a key predictor for customer retention (e.g., Flavian et al. 2006; Gefen 2002; Qureshi et al. 2009), due to its crucial ability to promote risk-taking behavior in the case of uncertainty, interdependence, and fear of opportunism (Mayer et al. 1995; McKnight et al. 1998).

However, the impact of trust on online repurchase is not independent from its context, which has recently led researchers to call for further exploration of an additional area of concern: the moderating effect of the e-commerce institutional context on the relationship between trust and online repurchase (Gefen et al. 2008), where the institutional context refers to formal regulative structures initiated to safeguard the transaction environment (Zucker 1986). Following this call, the first objective of our study is to investigate this moderating effect due to its potential theoretical and practical significance. Theoretically, it presents a research opportunity to investigate how trust operates under various boundary conditions (Gefen et al. 2008). The findings could help specify regulative conditions under which trust has varying effects on online purchase (Gefen and Pavlou 2006), and explain the somewhat unexpected results in the literature that trust has a much less significant effect on customer e-loyalty ${ }^{1}$ (e.g., Ribbink et al. 2004) than in other related studies (e.g., Flavian et al. 2006; Gefen 2002; Li et al. 2006; Qureshi et al. 2009).

\footnotetext{
${ }^{1}$ Loyalty has been recognized as having multiple dimensions, such as retention, repurchase, and recommendation to others (e.g., Kim et al. 2009; Srinivasana et al. 2002) Among them, repurchase is recognized as a major manifestation of loyalty with most direct promise on financial returns, hence is highly desirable and commercially viable to online
} 
Practically, a complete understanding of this moderating effect can yield the potential of guiding online firms to fine-tune their online trust (re)production strategies. In today's hypercompetitive e-commerce environment, while customer trust increasingly becomes an essential factor, empirical studies reveal that the presence of trust alone may not be universally sufficient for triggering customer transaction intentions (Gefen and Pavlou 2006; Liu and Goodhue 2012; Van der Heijden et al. 2003). Viewing this trend from an online firm's perspective, their vast investment in building and maintaining a trustworthy image, whilst expensive, may no longer be a distinctive advantage, but more of a business necessity for ongoing operations (Barney and Hansen 1994). In this context, a better understanding of the moderating effect of the e-commerce institutional context is essential to inform online firms on how to more cost-effectively allocate their trust-building resources, and thereby optimize their return from investing in trust production.

Our second objective is to examine the moderating effect of the e-commerce institutional context on the relationship between past transaction performance (manifested as customer satisfaction) and trust in the online repurchase situation. Whilst prior research suggests that the institutional context directly affects customer trust in initial transaction relationships, it also implies that the institutional context may not play a role in affecting trust in the repurchase situation. This is because first-hand experience with the trustee in a repurchase situation is available and can serve as a dominating source for evaluating trust (McKnight et al. 1998). With this conjecture put forward, very few follow-up studies have further explored the effect of the institutional context on trust in the online repurchase situation (e.g., Kim et al. 2004). We argue that even though returning customers primarily rely on first-hand experience to re-evaluate trust, it is questionable to assume

vendors (e.g., Oliver 1999; Otim and Grover 2006). In our research, we use e-loyalty primarily to focus on its repurchase dimension and thus use it interchangeably with repurchase intention. 
that this effect of first-hand experience-based evaluation holds uniformly strong regardless of the effect of the institutional context. In fact, scholars have long suggested that the importance of previous transaction performance to the re-evaluation of trust is still dependent on the context (Mayer et al. 1995). Yet, prior research has largely ignored the potential effect of the institutional context in repurchase situations. There is a clear need to address this gap.

To meet these two objectives, our study addresses the moderating role of the e-commerce institutional context in the online repurchase situation, by investigating the perceived effectiveness of e-commerce institutional mechanisms (PEEIM) as a manifestation of the institutional context. PEEIM refers to online customer perceptions that third-party safeguarding mechanisms, such as online credit card guarantees, escrow services and privacy protection exist to protect them against potential risks in the e-commerce environment. Unlike existing similar concepts, PEEIM is developed to capture customer perceptions of the vendor-independent e-commerce institutional environment, and is framed to highlight its ability to mitigate risks. Drawing on the sociological (Fukuyama 1995; Lewis and Weigert 1985) and organizational (Mayer et al. 1995) theories of trust, we examine the extent to which PEEIM affects how customer online trust is affected by customer satisfaction (the evaluative outcome of first-hand transaction experience) and how trust influences online repurchase.

This study makes several important theoretical and/or empirical contributions to the ecommerce literature (see Table 1 for a summary). First, our study extends understanding of ecommerce institutional mechanisms by introducing PEEIM which stresses the mitigation of general contextual risks. Second, by establishing PEEIM as a key moderator on the relationship between trust and repurchase intention, our study advances existing e-commerce research on the effect of trust, by specifying an institutional boundary condition under which the behavioral effect 
of trust varies. Third, unlike prior studies which suggest that institutional mechanisms may be only important for evaluating trustworthiness in initial online purchasing contexts (McKnight et al. 2002a; McKnight et al. 2002b; McKnight et al. 1998) ${ }^{2}$, our study finds that institutional mechanisms remain important in online repurchase situations, by examining how the experiencebased evaluation of trust in a vendor (e.g. through satisfaction) is strengthened by PEEIM. Fourth, prior research implies that institutional mechanisms do not directly affect trust perceptions or behavioral intentions in existing relationships, with no empirical investigation (McKnight et al. 1998). Our study is among the first to provide such empirical evidence based on our sample in an online repurchase context.

Table 1 - Preview of Study Contributions

\begin{tabular}{|c|c|c|c|c|}
\hline No. & Contribution & State of the Literature & \multicolumn{2}{|c|}{ Relevance } \\
\hline & & & Theory & Empirics \\
\hline 1. & $\begin{array}{l}\text { Extends understanding of e- } \\
\text { commerce institutional } \\
\text { mechanisms by introducing } \\
\text { vendor-independent PEEIM that } \\
\text { highlights the ability to mitigate } \\
\text { general, contextual risks. }\end{array}$ & $\begin{array}{l}\text { Prior research either studies vendor- } \\
\text { specific institutional mechanisms (Pavlou } \\
\text { and Gefen 2004) or structural assurance } \\
\text { that is more general in nature (McKnight et } \\
\text { al. 1998) }\end{array}$ & $\checkmark$ & \\
\hline 2. & $\begin{array}{l}\text { Specifies the institutional } \\
\text { boundary condition under which } \\
\text { trust affects online repurchase } \\
\text { intention by establishing the } \\
\text { moderating role of PEEIM. }\end{array}$ & $\begin{array}{l}\text { Prior research highlights the need to } \\
\text { investigate the effect of social, institutional } \\
\text { contexts on the effect of trust in e- } \\
\text { commerce environments (Gefen et al. } \\
\text { 2008). }\end{array}$ & $\checkmark$ & \\
\hline 3. & $\begin{array}{l}\text { Advances the understanding that } \\
\text { institutional mechanisms remain } \\
\text { important in the context of online } \\
\text { repurchase, such that it moderates } \\
\text { the experience-based evaluation } \\
\text { (e.g. satisfaction) of trust in an } \\
\text { online vendor. }\end{array}$ & $\begin{array}{l}\text { Prior research on institutional mechanisms } \\
\text { primarily focused on initial online } \\
\text { purchase, and implied that institutional } \\
\text { mechanisms do not play a key role in } \\
\text { evaluating trustworthiness in the online } \\
\text { repurchase context (McKnight et al. 2002a; } \\
\text { McKnight et al. 2002b; McKnight et al. } \\
\text { 1998). }\end{array}$ & $\checkmark$ & $\checkmark$ \\
\hline 4 & $\begin{array}{l}\text { Provides empirical evidence to the } \\
\text { deduction that institutional } \\
\text { mechanisms do not directly affect }\end{array}$ & $\begin{array}{l}\text { Prior research implies that institutional } \\
\text { mechanisms do not directly affect trust } \\
\text { perception and trusting behavior in existing }\end{array}$ & & $\checkmark$ \\
\hline
\end{tabular}

\footnotetext{
${ }^{2}$ A follow-up study by McKnight et al. (2004) did not find empirical support that structural assurance would decrease over time in effectiveness in predicting two trusting beliefs and trusting intention.
} 
trust and transaction behavior in existing relationships. relationships, without any empirical investigation (McKnight et al. 1998). 


\section{Theoretical Background}

\subsection{Perceived Effectiveness of E-commerce Institutional Mechanisms}

Institutional mechanisms are impersonal structures implemented or created by third parties to create conditions that safeguard transaction success (Pavlou and Gefen 2004). In the traditional environment, these mechanisms include bureaucratic sanctions and safeguards that generalize beyond a given transaction and beyond specific sets of exchange partners (Zucker 1986). The institutional structures that characterize modern, complex societies, such as bank supervision of escrow accounts and legal employment contracts are common examples (Barber 1983; Lewis and Weigert 1985). These mechanisms are neither transaction-specific nor party-specific; rather, they are "external world known in common" [(Zucker 1986), p.63] and are institutionalized to guarantee that all the transactions will take place as promised. For example, escrow accounts are processed in standard terms, regardless of the characteristics of exchange partners.

Institutional mechanisms in the e-commerce environment have emerged in various forms in recent years. ${ }^{3}$ Common online safeguards include online credit card guarantees, escrow services and privacy protection (McKnight et al. 2002a; Pavlou and Gefen 2004). For instance, online escrow service providers (e.g. Paypal and SafeTrader) authorize payments only after the customer accepts the deal and agrees to pay, providing a safety net against potential risks in order fulfillment (Pavlou and Gefen 2004). Similarly, credit card online payment guarantees provide resources from financial institutions (e.g. credit card companies) to compensate buyers against potential fraudulent seller behavior (Pavlou and Gefen 2004). Although not an exclusive list, these third parties are

\footnotetext{
${ }^{3}$ Research has also identified market-driven factors, such as feedback mechanisms (i.e. reputation system) (Pavlou and Gefen 2004) and trust in the intermediary (Stewart 2003) as institutional structures. As they are mechanisms specific to rather than independent from particular transacting partners, we exclude them from the scope of our study.
} 
regarded as highly popular institutional mechanisms safeguarding today's e-commerce environment (Gefen et al. 2003; Pavlou and Gefen 2004).

With the established understanding of institutional mechanisms, we introduce the construct of Perceived Effectiveness of E-commerce Institutional Mechanisms (PEEIM), defined as an online customer's general perception that safeguards exist in the e-commerce environment to protect him/her from potential risks in online transactions. While some sociologists (e.g., Shapiro 1989; Zucker 1986) are concerned with objective, behavioral institutional mechanisms, our definition follows McKnight et al. (1998) and views the effect of institutional mechanisms largely in perceptual terms. Indeed, even though e-commerce institutional mechanisms have been rapidly developed in recent years and, from an objective point of view, can provide proper legal protection to online customers, different customers in the public domain may still have different perceptions of the effectiveness of these institutional mechanisms. Such differing perceptions may be a result of not having the need to use such mechanisms in the past and/or information learned about them from various external or anecdotal sources.

\subsection{Distinguishing PEEIM from Other Related Concepts}

The distinction of PEEIM could be better understood through a comparison with several similar constructs that have been widely used to define institutional mechanisms in the past, including institutional structures (Pavlou and Gefen 2004), perceived regulative effectiveness of marketplaces (PREOM) (Gefen and Pavlou 2006), and structural assurance (McKnight et al. 1998). While PEEIM appears to have overlaps with these constructs, they differ in terms of whether they are vendor-specific and the degree to which their effects are negatively framed. We summarize the key differences between PEEIM and other related concepts in Table 2. 
Table 2 - Distinctions between PEEIM and Related Concepts

\begin{tabular}{|c|c|c|c|}
\hline \multirow{2}{*}{\multicolumn{2}{|c|}{$\begin{array}{l}\text { Major } \\
\text { Institutional } \\
\text { Mechanisms }\end{array}$}} & \multicolumn{2}{|c|}{ Degree of Negative Risk Framing } \\
\hline & & Less & More \\
\hline \multirow{2}{*}{ 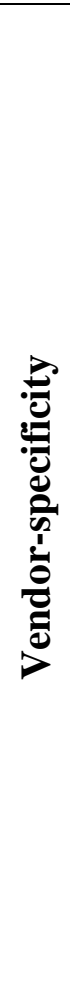 } & $\begin{array}{l}\text { General } \\
\text { (Vendor- } \\
\text { independent) }\end{array}$ & $\begin{array}{l}\text { Structural assurance (McKnight et al. } \\
\text { 1998; 2002a): General institutional } \\
\text { mechanisms highlight to customers that } \\
\text { safety and security of conducting e- } \\
\text { commerce transactions are assured } \\
\text { e.g. there are appropriate safeguards on } \\
\text { the Internet to assure success when } \\
\text { transacting online business }\end{array}$ & $\begin{array}{l}\text { PEEIM (this study): } \\
\text { General institutional mechanisms } \\
\text { highlight to customers that the risk of } \\
\text { loss from conducting e-commerce } \\
\text { transactions is reduced } \\
\text { e.g. there are appropriate safeguards } \\
\text { on the Internet to protect one against } \\
\text { any potential risks when transacting } \\
\text { online business }\end{array}$ \\
\hline & $\begin{array}{l}\text { Local } \\
\text { (Vendor- } \\
\text { specific) }\end{array}$ & $\begin{array}{l}\text { Institutional structure (Pavlou and Gefen } \\
\text { 2004; Pennington et al. 2003): a vendor } \\
\text { exhibits linkages to third-party } \\
\text { institutional mechanisms to assure } \\
\text { customers that transactions with the } \\
\text { vendor are secure } \\
\text { e.g. there are appropriate safeguards on } \\
\text { this website to assure success when } \\
\text { transacting online business through this } \\
\text { website. }\end{array}$ & $\begin{array}{l}\text { Unexplored: } \\
\text { A vendor exhibits linkages to third- } \\
\text { party institutional mechanisms to } \\
\text { signal that the risk of loss from } \\
\text { conducting transactions with the } \\
\text { vendor is reduced } \\
\text { e.g. there are appropriate safeguards } \\
\text { on this website to protect one against } \\
\text { any potential risks when transacting } \\
\text { online business through this website. }\end{array}$ \\
\hline
\end{tabular}

First, as shown in Table 2, PEEIM is defined at the general level, i.e. vendor-independent, which differentiates PEEIM from similar constructs such as institutional structure. Institutional mechanisms have been understood at two different levels in the extant literature: at the general level (i.e. independent from any specific online vendor) (McKnight et al. 2002a; McKnight et al. 2002b; McKnight et al. 1998) and at the local level (i.e. where the institutional mechanisms are examined in the context of a specific online vendor or marketplace) (Gefen and Pavlou 2006; Pavlou and Gefen 2004; Pennington et al. 2003). Institutional structure, which operates at the local level, captures the extent to which institutional structures provide assurances to online customers that their transactions with a specific online vendor will succeed, primarily through the 
mechanisms of trust transferences (Stewart 2003), guarantees (Zucker 1986) and signaling (Akerlof 1970). These vendor-specific mechanisms are useful in building trust and eliminating risks inherent in the transactional relationship with the specific vendor (Pavlou and Gefen 2004). However, they do not directly address risk inherent in the e-commerce environment beyond the vendor's control. ${ }^{4}$

Different from vendor-specific mechanisms, general institutional mechanisms, like PEEIM, could not only alleviate relationship-specific risks resulting from the conduct of the particular trustee (McKnight et al. 1998), but could also mitigate contextual risks that are "outside of considerations that involve the relationship with the particular trustee” (Mayer et al. 1995 p.726). The latter, also termed as system-dependent uncertainty (Grabner-Krauter and Kaluscha 2003), is beyond the direct influence of the trustee and is characterized as "uncertainty of the world" (Hirshleifer and Riley 1979). An example of such uncertainty in the e-commerce environment is potential technological sources of errors and security weaknesses that are not associated directly with the trustee involved in the transaction (Grabner-Krauter and Kaluscha 2003). Since uncertainty of this kind is not within the control of the online vendor, it cannot be completely addressed by vendor-specific institutional mechanisms. We define PEEIM at the general level to capture the distinctive ability of institutional mechanisms to mitigate this contextual uncertainty, which we later argue would be essential to enact the moderating effect we propose.

Second, PEEIM is defined to be more explicit in its negative framing on risk, which differentiates PEEIM from another conceptually closer construct: structural assurance, as shown

\footnotetext{
${ }^{4}$ Perceived regulative effectiveness of marketplaces (PREOM) also operates at the local level, i.e. specific to an emarketplace, and thus is not vendor-independent. We believe that PREOM falls outside of Table 2 for the following reason. According to Gefen and Pavlou (2006, p.1314), there is a major conceptual distinction between PREOM and all the constructs in Table 2. Specifically, PREOM is about the management of the marketplace proactively taking action to regulate the marketplace as a way of enforcing appropriate conduct, whereas the constructs included in Table 2 are all about third-party bodies reactively responding to complaints and ex post attempts to address conflicts.
} 
in Table 2. Originally construed in broad social and economic situations (Shapiro 1989), structural assurance is defined as individual general beliefs that contextual conditions such as promises, contracts, regulations, and guarantees are in place to assure success in an organizational context (McKnight et al. 1998). Follow-up studies extend structural assurance to the e-commerce context by referring to it as the extent to which online customers believe that legal and technological Internet safeguards (e.g. security measures) protect them from privacy or identity loss, or credit card fraud (McKnight and Chervany 2002; McKnight et al. 2002a). Thus, PEEIM and structural assurance appear to share a good degree of conceptual similarity in terms of their respective definitions.

However, PEEIM and structural assurance differ in terms of their degree of negative framing on risk. Structural assurance focuses on the effect of institutional mechanisms in providing protections and assurance, whereas PEEIM, as is conceptualized here and measured later in the paper, more explicitly highlights its effect in mitigating risks. For instance, McKnight et al. (2002a) primarily frame the effect of Internet third-party safeguards by using phrases related to assurance provision, such as “[safeguards] make me feel comfortable using it to transact personal business”, or "make it safe for me to do business" (p.355). Thus, this construct is framed towards being neutral, if not positive, when describing the protective effect of the safeguards. In comparison, we develop PEEIM to frame the effect of third-party safeguards with an explicit emphasis on reducing risks, by, for instance, highlighting that the third-party safeguards could "protect one against potential risks of online shopping such as leaking of personal information and credit card fraud.” Thus, while it appears that both types of framing recognize the possibility of negative outcomes (i.e. 
potential of loss) and promise the prospect of staying safe (by mitigating risks), PEEIM places more emphasis on risk than does structural assurance. ${ }^{5}$

The theoretical implications of these two slightly different framings can be explained by the framing effects of prospect theory (Kahneman and Tversky 1979). According to the theory, the utility function of most people is reference-dependent, i.e. the expected utility derived from taking a chance would be perceived differently if the reference point is set differently. Specifically, because people are generally loss-averse, their expected utility resulting from taking a chance would be higher when the expected result is framed as reducing loss than keeping gains (Kahneman and Tversky 1979) ${ }^{6}$. Consistent with the theory, Sitkin and Pablo (1992) in their study on risk-taking behavior, suggest that the same scenario for a risk-taking decision, if framed negatively to people by stressing loss, would lead to a higher chance of them conducting the risktaking behavior, than if it is framed positively. Psychology research on positive and negative valence arrives at the same conclusion (Cacioppo and Berntson 1994).

According to the above framing effect stated in prospect theory (Kahneman and Tversky 1979), when e-commerce institutional mechanisms are more strongly framed as the mechanisms for loss reduction (through risk mitigation), online customers would more likely appreciate the prospective value of these mechanisms and therefore attach more importance to the loss reduction function of

\footnotetext{
${ }^{5}$ The conceptual distinctions between the two constructs were demonstrated through a separate mini survey conducted to empirically differentiate the two constructs. We were able to collect about 124 responses from 325 university personnel in the business school of a large university with experience in online shopping. The nested model comparison (chi-square difference test, Anderson and Gerbing 1988) supported the discriminant validity, and square root of average variance extracted (AVE) for each of the constructs was substantially larger than the correlation between these two constructs. In addition, we also examined loadings and cross-loadings to assess whether there was any measurement overlap between the constructs. The items of structural assurance and PEEIM clearly loaded onto their respective constructs (the highest cross-loading was 0.4). The results indicate that, while correlated with each other ( $\gamma=0.57$, which is not surprising given their conceptual similarity), PEEIM demonstrates good discriminant validity from structural assurance. See Appendix IV for the detailed analysis.

${ }^{6}$ For example, the utility of a measure framed to stop a situation where one would lose $\$ 400$ from a total of $\$ 600$ would sound more attractive than if it is framed to help keep \$200. Kahneman and Tversky (1981) used a similar example in the context of life saving.
} 
these mechanisms. Such enactment of importance attached to loss reduction, which is more explicitly reflected in PEEIM, is desired in our investigation because, as we will explain later in the hypothesis development section, the role of institutional mechanisms in the online repurchases situations lies in the risk-mitigation function. Thus, compared with structural assurance, we investigate PEEIM in our study due to its relatively strong manifestation of the risk-mitigation mechanism.

\subsection{The Effect of E-commerce Institutional Mechanisms}

The effects of e-commerce institutional mechanisms have been mainly studied in the context of initial online purchase. First, structural assurance and institutional structure are consistently found to directly promote initial trusting belief in an online vendor (McKnight et al. 2002b; Pavlou and Gefen 2004; Vance et al. 2008) due to trust transference, where perceptions about the security of the transaction context are likely to affect the perceptions of the trustee in that context (Stewart 2003) ; or due to cognitive consistency (Abelson et al. 1968), where one's perception of institutional mechanisms likely results in consistent perceptions of the trustee. Second, structural assurances are also found to directly affect initial purchase intention because customers rely on second-hand information from trustworthy third parties to feel assured about transacting with an unknown vendor (McKnight et al. 2002a; McKnight et al. 2002b; McKnight et al. 1998).

In contrast to the fruitful research findings on the role of institutional mechanisms in the context of initial online purchase, research efforts spent in extending the understanding of ecommerce institutional mechanisms to the context of online repurchase have been limited. The only related seminal work, yet with the primary theoretical focus on initial trust formation, conjectures that institutional mechanisms may not take effect in existing relationships (e.g. online repurchase), because first-hand experience with the trustee could take over as a dominating source 
for re-evaluating trust (McKnight et al. 1998). Empirical research adding evidence to this conjecture has been rare, with very few exceptions (Kim et al. 2004).

In view of this gap, we aim to contribute to the literature by extending the understanding of ecommerce institutional mechanisms to the online repurchase context. It is our premise that, although institutional mechanisms may not directly affect trust or behavioral intention in repeated online transactions with a vendor, they may still play a role through their ability to mitigate contextual risks, i.e. those outside considerations of the relationship with any particular vendor. In the next section we argue that PEEIM, which is defined at the general level and framed to highlight the role of contextual risk mitigation, could still have important consequences in affecting trust evaluation and online repurchase intention by managing customers' perceptions of e-commerce environmental uncertainties underlying repeated online transactions.

\section{Research Framework and Hypotheses Development}

In this section we develop a research model to explain the role of PEEIM in setting a contextual condition under which (1) online customer trust affects online repurchase intention, and (2) online customers evaluate trust through first-hand information about the vendor (i.e. satisfaction) as depicted in Figure 1. Specifically, in what follows we first argue, by drawing on the organizational trust literature, that PEEIM negatively moderates the relationship between online customer trust and repurchase intention. Then, we introduce customer satisfaction with vendor to represent customers' past evaluations on first-hand information about a vendor, and then argue that PEEIM positively moderates the relationship between customer satisfaction and trust in the vendor. 


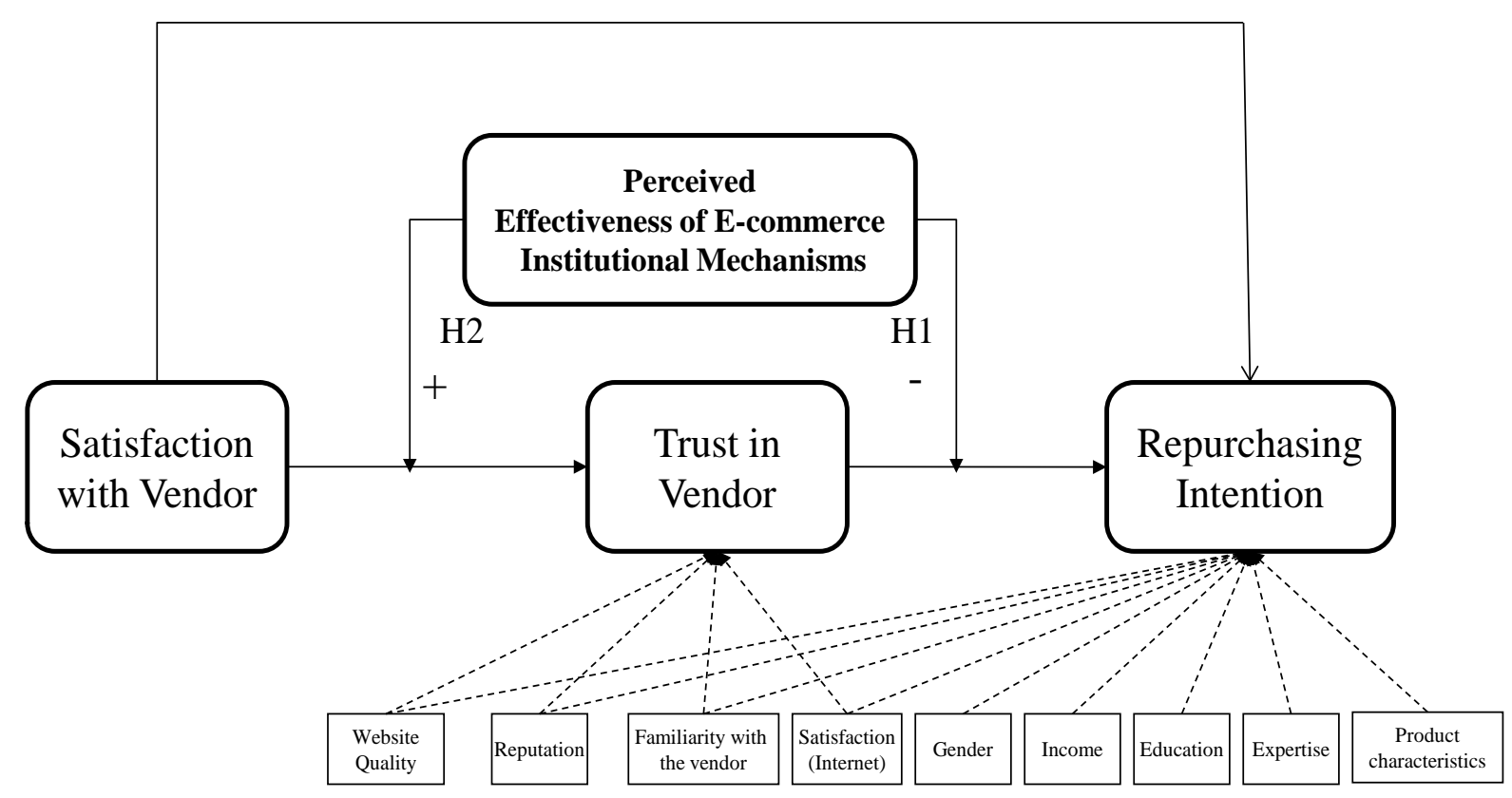

Figure 1 - Research Model

\subsection{The Moderating Role of PEEIM between Trust and Online Repurchase}

Trust is a belief that trusted parties will behave in accordance with the trusting party's confident expectations by exhibiting ability, integrity and benevolence (Luhmann 1979; Mayer et al. 1995). Trust is a key mechanism governing exchange relationships characterized by uncertainty, vulnerability, and dependence (Bradach and Eccles 1989). Trust promotes transaction success because it can reduce social uncertainties that would otherwise be too complex, if not impossible, to figure out on a rational basis (Luhmann 1979). In other words, it can reduce perceptions of risk(s) to a more manageable level by allowing customers to rule out, subjectively, the potentially undesirable behaviors by the party they trust (Mayer et al. 1995). For this reason, trust has been found to be a key predictor of both initial online purchase and repeat purchase (e.g., Flavian et al. 2006; Gefen 2002; Li et al. 2006; Lim et al. 2006; Qureshi et al. 2009).

In a repurchase situation, PEEIM serves to mitigate customers' perceptions of contextual risks inherent in the general e-commerce environment which are independent from online vendors 
(Grabner-Krauter and Kaluscha 2003). For example, online customers may suffer from loss through credit card fraud or loss of privacy due to the security issues of the public Internet infrastructure, which is independent of the vendor in any particular transaction (McKnight et al. 2002b). Mayer et al. (1995) argue that risk-taking behavior, such as repurchase decision in our case, is a function of trust and the perceived contextual risk of the behavior: "If the level of trust surpasses the threshold of perceived risk, then the trustor will engage in the risk-taking behavior" (Mayer et al. 1995 p.726). They further concluded that perceived contextual risk or uncertainty is one of the situational factors that "necessitate trust: "the need for trust only arises in a risky situation” (p. 711). Indeed, Schlosser et al (2006) show that trust has little effect on purchase intention under the context of low perceived risk. This implies that risk-mitigation mechanisms could be leveraged to change the necessity of trust in risk-taking behavior.

E-commerce institutional mechanisms create a less risky transaction environment by reducing contextual uncertainties through explicit regulatory assurances (Shapiro 1989) which enables people to rely less on trust to continue a transaction. According to Luhmann (1979) trust is not a factor determining behavioral intention in a community of little uncertainty. As institutional mechanisms are available to mitigate contextual risks in the transaction environment the need for customer trust in promoting repurchasing decisions is lessened (Corritore et al. 2003; Fukuyama 1995). For instance, Ball et al. (2006) observed that trust has little impact on customer loyalty when the trustees (banking sector) operate “...by virtue of both strong government oversight and strong industry tradition...” (p. 1284). This implies that when institutional mechanisms are effective in regulating the transaction environment, customers may rely less heavily on trust in a vendor to form repurchase intentions. 
In contrast, if online consumers have little confidence in the effectiveness of institutional mechanisms to set and enforce appropriate rules of conduct in the e-commerce environment then customers need additional assurance - especially those that are transaction-specific - for increasing their confidence in buying from the vendor. As a result, customers must depend more heavily on trust in the online vendor to obtain the necessary assurance (Corritore et al. 2003; Mayer et al. 1995). Given PEEIM operates at the general level and explicitly signals the risk mitigation function to online customers, we believe PEEIM moderates the trust-repurchase relationship:

H1: A returning customer's perceived effectiveness of institutional mechanisms (PEEIM) negatively moderates the relationship between trust in an online vendor and repurchase intention, such that trust in the vendor influences repurchasing intention less strongly when PEEIM is higher.

\subsection{The Moderating Role of PEEIM between Satisfaction and Trust}

In online repurchase contexts, returning customers' trust in an online vendor needs to be maintained and continually evaluated (Qureshi et al. 2009). Unlike new customers who must assess a vendor based on second-hand information and/or visual cues (e.g., Kim and Benbasat 2006; Kim and Benbasat 2009), returning customers have a unique approach to assessing a vendor's trustworthiness in online repurchase contexts: they have direct transaction experience with the vendor and thus possess experience-based, first-hand knowledge to re-evaluate an online vendor's trustworthiness (Holmes 1991; Lewicki and Bunker 1995). This is consistent with what Zucker (1986) summarized as the process-based source of trust production, and has also been discussed as an outcome-based (re-)evaluation of trust by Mayer et al (1995). The experiential knowledge about the vendor that has been accumulated through the past interaction process is often strong enough to be a primary source of trust (Sitkin and Roth 1993). As our study is intentionally situated in the online repurchase context, we focus on this experienced-based mechanism of trust production, specifically the notion of previous satisfaction with the vendor. 
Satisfaction is referred to as an evaluative outcome based on past exchanges with the trustee, with the evaluation based on past similar experiences being the most influential (Holmes 1991). To save cognitive effort, people tend to form a stable set of beliefs based on past experience which can be conveniently retrieved to infer new situations (Kim et al. 2005; Louis and Sutton 1991). A customer's satisfaction with a vendor signals the vendor's performance of the equitable outcomes and welfare of the customer during their past exchanges and thus demonstrates the customer service ethos (e.g. caring) of the vendor, a core component of trust. Satisfaction also reflects the perception of the trustee's effective performance in terms of reliability and expertise in fulfilling past transactions (Ganesan 1994) indicating that the trustee will have the integrity and ability to successfully deal with future transactions. Hence, a successful, and thus satisfying past exchange, enables the trustor to form a positive evaluation of the past exchange process which updates the trustor's confidence that the trustee will have the benevolence, integrity and ability to succeed with future exchanges (i.e. trust) (Mayer et al. 1995). Indeed, empirical support has been found for the effect of satisfaction on trust in both offline (Bauer et al. 2002; Berry and Parasuram 1991; Ganesan 1994) and online business relationships (Flavian et al. 2006; Kim et al. 2004; Li et al. 2006; Ribbink et al. 2004) ${ }^{7}$.

While people tend to rely on their past experience to inform their assessments of current decisions, the level of reliance depends on the certainty of the context. This is modeled as a positive moderating effect of PEEIM on the influence of a person's favorable past experience with a vendor (as manifested by his/her satisfaction with the vendor) on trust in the vendor ( i.e., when PEEIM

\footnotetext{
${ }^{7}$ It is noteworthy that trust has also been argued to influence satisfaction (Andaleeb 1996). The rationale for the influence of trust on satisfaction is that trust implies the beliefs in the positive outcomes of the trustee's actions which could lead to satisfaction with the relationship with the trustee. Consistent with cognitive-based trust building, we choose the causal direction from satisfaction to trust, viewing trust as the consequence of the capacity of the vendor (trustee) to satisfy the needs of its customers (Flavian et al. 2006).
} 
is high, the influence of user satisfaction on trust is strong and when PEEIM is low, it is weak). When PEEIM is high, the transaction environment is protected by high PEEIM and thus has low uncertainty. In such a certain and stable environment, peoples' "ingrained cognitive script" is formed based on their past experience and can be activated automatically without conscious information processing e.g. automatic thinking (Kim et al. 2005; Louis and Sutton 1991). In other words, customers do not evaluate the same vendor in every transaction with them, but instead rely on their past experience with this vendor. Past experience is a reliable information cue to inform future decisions, and helps to form stable long-term relationships. People give more weight to past experience in such certain and stable situations. The trustworthiness, as reflected by user satisfaction, will be conveniently applied to infer customer trust in the current transaction.

On the contrary, when PEEIM is low (i.e., customers perceive the e-commerce environment to be uncertain), the automatic reliance on prior experience can be interrupted by the uncertain or discrepant situations because situational uncertainty may make customers question the applicability of the past experience to new situations (Louis and Sutton 1991). For example, the reliance on a past satisfactory experience can be interrupted by critical unexpected incidents that occur in the vendor-customer relationship (Doorn and Verhoef 2008). In such a context people tend to be mindful and collect new information about the current decision rather than relying on past experience. This implies a weaker influence of user satisfaction on trust. In other words, the uncertain environment serves as a trigger for people to switch from automatic reliance on past experience to actively looking for and processing new transaction specific information to determine the trustworthiness of the current online transaction situation (Louis and Sutton 1991). That is, they will be more mindful and collect more current information, rather than inferring from 
past experience, to form their trust perceptions. As a result, the influence of user satisfaction on trust is diluted. Thus, we hypothesize:

H2: A returning customer's perceived effectiveness of institutional mechanisms (PEEIM) positively moderates the relationship between customer satisfaction and trust in the vendor, such that satisfaction positively influences trust in the vendor more strongly when PEEIM is higher.

\section{Methodology}

A survey was designed to test the proposed model. We chose the survey method because it is best adapted to obtaining personal and social facts, beliefs and attitudes, and it also enjoys the merit of enhancing the generalizability of research findings (Kerlinger 1973).

\subsection{Measurement Development}

As most constructs in this study (i.e. repurchase intention, trust, satisfaction) have been well established in the existing literature we used/adapted previously validated measures as appropriate. We subjected all the adapted items to the validation procedures described in the literature (Moore and Benbasat 1991). We followed the commonly accepted advice on wording questions when developing and finalizing the questionnaire (de Vaus 1995). To ensure content validity we asked subject matter experts to review the questionnaire. The questionnaire was piloted among 12 staff and 10 students in a large university before being accepted as the final version. No items were dropped from the pilot. Appendix I lists the measurement items and their sources.

The measures for PEEIM were carefully developed. While Pavlou et al. (2004) measured perceived effectiveness of escrow services and credit card guarantees separately, we created four items to measure PEEIM by capturing online customers' perception of e-commerce third-party safeguards as a whole (see Appendix I). To correspond to our conceptualization and thus ensure construct validity, the items were carefully worded to refer to the perception of institutional 
mechanisms in general, rather than being specific to any online vendor. Also, the items were worded to explicitly highlight the role of risk mitigation so as to induce the expected framing effect. In addition, to ensure that the meaning of institutional mechanisms was clear, we gave examples of institutional mechanisms that respondents could relate to (i.e. escrow services and credit card guarantees). As a result, the construct reliability for this factor was high (Cronbach’s alpha $>$.79) and an exploratory factor analysis showed that all the items loaded on a single factor. Three out of the four factor loadings were within the acceptable range. The other was below the acceptable cutoff (< 0.7) (Nunnally and Bernstein 1994) and was dropped from further analysis.

We also included several control variables in our model to ensure that the empirical results are not due to covariance with other variables. Previous literature suggests that shoppers' gender, income, level of education and expertise in using the Internet may affect the intention to purchase on the Internet (Pavlou and Fygenson 2006; Van Slyke et al. 2002). Vendor reputation is also identified as a strong factor influencing returning customers' trust in the vendor (Jarvenpaa and Tractinsky 1999; Jarvenpaa et al. 2000). Website quality is identified as a strong factor influencing both returning customers' trust in the vendor and repurchase intention (Qureshi et al. 2009; Zhang et al. 2011). Likewise, online customers' familiarity with the vendor and their satisfaction with previous transactions on the Internet (not specific to the vendor concerned) are included as control variables (Flavian et al. 2006; Gefen 2002). We also controlled for the known direct relationship between satisfaction with the vendor and repurchase intention (Kim et al. 2009). Finally, it is likely that product characteristics might affect repurchase intention. In order to account for this, we also included product price and product type as control variables in our model.

\subsection{Survey Design}


The survey included two parts. The first part was used to measure respondents' general perceptions of online shopping (i.e. PEEIM, Satisfaction with Purchasing via the Internet, and Expertise in Using the Internet to Conduct Transactions). To ensure that respondents would not have any online vendors in mind when answering these general-level questions we created a separate section explicitly soliciting "general beliefs about online purchasing" at the very beginning of the survey questionnaire before the section on questions specific to an online vendor (see Appendix I).

The second part of the survey used a recall method to solicit respondents' perceptions of a recent purchase experience with an online vendor. Recall method is typically used to tap into individuals' long-term memory where information specific to one's personal history or experiences is stored. It has been used as a valid approach to collect perceptual data in the marketing literature (e.g. Bagozzi and Silk 1983; Gardial et al. 1994). Similarly, prior IS research has shown individuals, through the process of recalling, effectively access and retrieve their long-term memory to facilitate the formation of current perceptions and behavior (Kim 2009).

We followed the guidance provided in the marketing literature to help respondents effectively retrieve information stored in their memory (Bagozzi and Silk 1983; Bradburn 2004). To encourage the respondents to focus on a most recent and therefore best memorized purchase experience we asked them to "think of a vendor you have purchased from recently via the Internet" (and also bear it in mind as they filled out the questionnaire). They were also asked to write down the vendor's name and website address before proceeding to answer the survey questions (see Appendix I). This exercise served as a "retrieval cue" to trigger the memory of the experience with the vendor (Tulving 1983). Moreover, we provided additional stimulus cues to facilitate recall by ensuring the usage of validated measurement items that are highly relevant in an online 
purchasing context (Sudman and Bradburn 1973). Finally, we believe that recall method, such as the one used in this study, are particularly applicable to the repurchase context because customers often recall their previous purchase behavior when they repurchase from the same vendor. In this sense, the recall method actually simulates the process through which people form their perceptions about repurchasing.

\subsection{Data Collection}

Data to test the research model were collected from a sample of university personnel. Respondents were instructed to complete the questionnaire only if (1) they had prior purchasing experience from an online website and (2) the product(s) or service(s) bought was/were for personal use. This overcame the problem of respondents answering questions relating to purchases they made online on behalf of the university.

A total of 865 questionnaires were distributed: 170 to a random sample of university staff and 695 to a sample of students attending business courses at the university. There were 362 useable responses, resulting in a $42 \%$ response rate. The mean age of the respondents was approximately 29, $\min / \max$ values were 19 to 64 and the standard deviation was 9.5. Respondents comprised $70 \%$ females and $30 \%$ males $^{8}$. In terms of the highest level of education completed respondents were well spread: $33 \%$ had high school certificates, $21 \%$ had college degrees, $41 \%$ had university graduate degrees, and $5 \%$ had university postgraduate degrees.

Air tickets were the most common item bought $(\mathrm{n}=92)$ followed by books $(\mathrm{n}=42)$, clothes ( $\mathrm{n}=37)$, DVDs $(\mathrm{n}=18)$, sports gear $(\mathrm{n}=12)$ and other items such as hotel room bookings, household

\footnotetext{
${ }^{8}$ Our sample had a higher proportion of women, compared to a commonly reported range of $53 \%$ to $60 \%$ women among online shoppers. Buysight (http://www.buysight.com/blog/2010/04/23/whos-shopping-online/), based on Forrester research, PEW online survey information and Nielson data, estimated that $56 \%$ of online shoppers are female. We used this proportion to perform random sub-sampling with replacement such that the resulting sub-sample had 56\% women and $44 \%$ men. We kept the sample size at 362, in order to have comparable power with the original analysis. The results of this robustness analysis were comparable with our original analysis.
} 
items, kitchen utensils, fishing equipment, TVs, cameras, watches, and so forth. The cost of the goods/services involved ranged between USD \$6.20 and \$6200 with a mean of \$207 and a standard deviation of $\$ 527$. In terms of tangible and intangible items the breakdown was $62 \%$ tangible and $38 \%$ intangible.

Non-response bias was estimated using the method suggested by Armstrong and Overton (1977). We compared early respondents with late respondents for all the constructs, including the control variables. None of the t-statistics for difference in means were statistically significant, suggesting that non-response bias was not an issue.

The common methods bias test was performed by following Harman's single-factor test (Podsakoff et al. 2003; Podsakoff 1986). The analysis confirms that the threat of common method bias was minimal (Lindell and Whitney 2001; Richardson et al. 2009). ${ }^{9}$

\subsection{Data Analysis Technique}

The research model was tested using Partial Least Squares (PLS), a component based structural equation modeling technique that enables path analytic modeling using latent variables (Chin et al. 2003; Qureshi and Compeau 2009; Wold 1982). PLS is regarded as an appropriate statistical tool for theory exploration (Jöreskog and Wold 1982) which is the case in our study. Path significance was assessed using bootstrap statistics with a total of 500 re-samples and 362 cases per sample (Lohmöller 1982). Moderating relationships were assessed using the product indicator method first developed by Judd and Kenny (1984) and later implemented in PLS by Chin et al. (PLS-PI) (2003); that is, interaction terms were created by multiplying the indicators of the predictor and moderator

\footnotetext{
${ }^{9}$ In this method, all the items in a study are subject to exploratory factor analysis. In our analysis we included all the items of all the latent variables (including control variables) in our model. A single factor did not emerge from this analysis, and the first factor explained only $16 \%$ of the variance in the variables. There were eight factors with eigenvalues over 1.0 , which collectively explained $76 \%$ (cumulative) of the variance.
} 
constructs. Each indicator of moderator and predictor was centered before performing multiplication.

\section{Results}

\subsection{Measurement Model}

To test the measurement model, we examined the internal consistency (reliability) and the convergent and discriminant validity of the constructs (Barclay and Higgins 1995; Carmines and Zeller 1979). Table 3 showed that internal consistency reliabilities (ICR) for each of the latent variables exceeded 0.70, suggesting good reliability (MacKenzie, Podsakoff, and Podsakoff 2011). The square root of average variance extracted (AVE), a measure of convergent validity, for each construct was greater than the recommended level 0.5 (Table 3) (Fornell and Larcker 1981). In addition, Table 4 showed that all the retained items had loadings greater than the recommended 0.7 cutoff (Carmines and Zeller 1979), and that items loaded well on their respective factors. These test results demonstrate good convergent validity

To assess discriminant validity, we used multiple techniques. First, through chi-square difference test (Anderson et al 1988; Joreskog 1993), it was confirmed that correlations between each pair of constructs were significantly different from "unity” (i.e. 1.0). Second, we observed the correlation matrix in Table 3, finding that the largest correlation was 0.49 , less than recommended 0.71 (Mackenzie et al 2011). Also, these construct correlations were lower than the square root of AVE of their respective constructs (Fornell and Larker 1981). Finally, according to Table 4, all the items loaded well onto their own construct and poorly on other constructs. All these test results suggest good discriminant validity.

\section{Table 3: Construct Correlation, Internal Consistency Reliability and the Square Root of AVE}

Satisfaction with the Internet (SI)

Vendor's Reputation (VR)

Repurchasing Intentions (RPI)

ICR*

\begin{tabular}{|c|c|c|}
\hline 0.92 & $0.88^{a}$ & \\
\hline 0.90 & 0.30 & 0.90 \\
\hline 0.87 & 0.39 & 0.30 \\
\hline
\end{tabular}

RPI

PEEIM

TV

SV $\quad$ PWQ




\begin{tabular}{|c|c|c|c|c|c|c|c|c|c|}
\hline PEEIM & 0.89 & 0.38 & 0.16 & 0.12 & 0.86 & & & & \\
\hline Trust in Vendor (TV) & 0.95 & 0.40 & 0.49 & 0.48 & 0.21 & 0.83 & & & \\
\hline Satisfaction with Vendor (SV) & 0.92 & 0.27 & 0.21 & 0.29 & 0.09 & 0.13 & 0.87 & & \\
\hline Perceived Website Quality (PWQ) & 0.93 & 0.23 & 0.24 & 0.24 & 0.09 & 0.29 & 0.24 & 0.71 & \\
\hline Expertise (EXP) & 0.93 & 0.38 & 0.24 & 0.19 & 0.31 & 0.18 & 0.34 & 0.26 & 0.88 \\
\hline
\end{tabular}

\begin{tabular}{|c|c|c|c|c|c|c|c|c|c|}
\hline Construct & Items & SI & VR & $R P I$ & PEEIM & $T V$ & $S V$ & $P W Q$ & $E X P$ \\
\hline \multirow{3}{*}{$\begin{array}{l}\text { Satisfaction with the } \\
\text { Internet (SI) }\end{array}$} & SI1 & 0.92 & 0.34 & 0.40 & 0.35 & 0.42 & 0.25 & 0.22 & 0.36 \\
\hline & SI2 & 0.91 & 0.25 & 0.33 & 0.32 & 0.32 & 0.20 & 0.30 & 0.34 \\
\hline & SI3 & 0.83 & 0.20 & 0.31 & 0.33 & 0.32 & 0.25 & 0.32 & 0.32 \\
\hline \multirow{2}{*}{$\begin{array}{l}\text { Vendor's Reputation } \\
\text { (VR) }\end{array}$} & VR1 & 0.29 & 0.90 & 0.31 & 0.18 & 0.43 & 0.25 & 0.23 & 0.24 \\
\hline & VR2 & 0.26 & 0.90 & 0.23 & 0.11 & 0.45 & 0.13 & 0.31 & 0.30 \\
\hline \multirow{3}{*}{$\begin{array}{l}\text { Repurchasing } \\
\text { Intentions (RPI) }\end{array}$} & RPI1 & 0.31 & 0.16 & 0.84 & 0.10 & 0.35 & 0.27 & 0.35 & 0.12 \\
\hline & RPI2 & 0.36 & 0.28 & 0.84 & 0.15 & 0.48 & 0.18 & 0.28 & 0.17 \\
\hline & RPI3 & 0.32 & 0.31 & 0.82 & 0.05 & 0.38 & 0.29 & 0.31 & 0.10 \\
\hline \multirow{3}{*}{ PEEIM } & PEELM1 & 0.40 & 0.15 & 0.17 & 0.88 & 0.22 & 0.10 & 0.22 & 0.32 \\
\hline & PEELM2 & 0.33 & 0.14 & 0.10 & 0.90 & 0.21 & 0.06 & 0.21 & 0.30 \\
\hline & PEELM3 & 0.23 & 0.12 & 0.04 & 0.79 & 0.10 & 0.07 & 0.10 & 0.29 \\
\hline \multirow{8}{*}{ Trust in Vendor (TV) } & TV1 & 0.40 & 0.53 & 0.45 & 0.17 & 0.84 & 0.14 & 0.17 & 0.17 \\
\hline & TV2 & 0.30 & 0.42 & 0.45 & 0.11 & 0.83 & 0.09 & 0.11 & 0.12 \\
\hline & TV3 & 0.34 & 0.39 & 0.36 & 0.21 & 0.83 & 0.06 & 0.21 & 0.20 \\
\hline & TV4 & 0.29 & 0.38 & 0.40 & 0.19 & 0.78 & 0.14 & 0.19 & 0.18 \\
\hline & TV5 & 0.26 & 0.27 & 0.26 & 0.13 & 0.74 & 0.09 & 0.13 & 0.14 \\
\hline & TV6 & 0.25 & 0.36 & 0.39 & 0.15 & 0.84 & 0.12 & 0.15 & 0.16 \\
\hline & TV7 & 0.38 & 0.40 & 0.38 & 0.23 & 0.88 & 0.08 & 0.23 & 0.19 \\
\hline & TV8 & 0.43 & 0.48 & 0.49 & 0.19 & 0.88 & 0.16 & 0.19 & 0.18 \\
\hline \multirow{4}{*}{$\begin{array}{l}\text { Satisfaction with } \\
\text { Vendor (SV) }\end{array}$} & SV1 & 0.54 & 0.50 & 0.48 & 0.15 & 0.47 & 0.84 & 0.27 & 0.42 \\
\hline & SV2 & 0.47 & 0.50 & 0.42 & 0.12 & 0.40 & 0.89 & 0.20 & 0.43 \\
\hline & SV3 & 0.48 & 0.33 & 0.37 & 0.17 & 0.40 & 0.88 & 0.21 & 0.39 \\
\hline & SV4 & 0.40 & 0.26 & 0.41 & 0.15 & 0.33 & 0.86 & 0.23 & 0.42 \\
\hline \multirow{13}{*}{$\begin{array}{l}\text { Perceived Website } \\
\text { Quality (PWQ) }\end{array}$} & PWQ1 & 0.22 & 0.23 & 0.32 & 0.17 & 0.16 & 0.23 & 0.72 & 0.23 \\
\hline & PWQ2 & 0.30 & 0.27 & 0.28 & 0.21 & 0.12 & 0.20 & 0.72 & 0.27 \\
\hline & PWQ3 & 0.32 & 0.25 & 0.31 & 0.12 & 0.19 & 0.22 & 0.85 & 0.25 \\
\hline & PWQ4 & 0.22 & 0.17 & 0.35 & 0.22 & 0.17 & 0.25 & 0.84 & 0.24 \\
\hline & PWQ5 & 0.30 & 0.21 & 0.29 & 0.19 & 0.14 & 0.27 & 0.76 & 0.23 \\
\hline & PWQ6 & 0.31 & 0.32 & 0.30 & 0.13 & 0.15 & 0.19 & 0.87 & 0.30 \\
\hline & PWQ7 & 0.23 & 0.22 & 0.33 & 0.20 & 0.21 & 0.21 & 0.75 & 0.24 \\
\hline & PWQ8 & 0.30 & 0.31 & 0.32 & 0.23 & 0.18 & 0.24 & 0.76 & 0.28 \\
\hline & PWQ9 & 0.30 & 0.25 & 0.31 & 0.15 & 0.17 & 0.27 & 0.70 & 0.25 \\
\hline & PWQ10 & 0.21 & 0.31 & 0.27 & 0.12 & 0.13 & 0.23 & 0.87 & 0.29 \\
\hline & PWQ11 & 0.30 & 0.22 & 0.28 & 0.14 & 0.21 & 0.25 & 0.83 & 0.25 \\
\hline & PWQ12 & 0.32 & 0.25 & 0.29 & 0.19 & 0.20 & 0.28 & 0.73 & 0.25 \\
\hline & PWQ13 & 0.33 & 0.24 & 0.35 & 0.22 & 0.13 & 0.27 & 0.74 & 0.24 \\
\hline Expertise (EXP) & EXP1 & 0.34 & 0.25 & 0.17 & 0.28 & 0.19 & 0.35 & 0.24 & 0.92 \\
\hline
\end{tabular}




\begin{tabular}{|l|l|l|l|l|l|l|l|l|l|}
\hline & EXP2 & 0.35 & 0.26 & 0.19 & 0.31 & 0.17 & 0.33 & 0.25 & $\mathbf{0 . 9 3}$ \\
\cline { 2 - 10 } & EXP3 & 0.33 & 0.19 & 0.21 & 0.29 & 0.16 & 0.34 & 0.20 & $\mathbf{0 . 8 8}$ \\
\hline & EXP4 & 0.32 & 0.22 & 0.18 & 0.33 & 0.20 & 0.29 & 0.31 & $\mathbf{0 . 7 9}$ \\
\hline
\end{tabular}

\subsection{Structural Model}

Figure 2 provides the results of the structural model. The model explains $48.4 \%$ of the variance in Trust in Online Vendor and 37.97\% of the variance in Repurchasing Intention. As shown in Figure 2, H1, which stated that PEEIM negatively moderates the relationship between Trust in Vendor and Repurchase Intention, was supported $(\beta=-0.124, \mathrm{t}=1.71, \mathrm{p}<0.05$, one-tailed). We plotted this moderating effect in Figure 3. As predicted, at low levels of PEEIM (mean - standard deviation), Repurchase Intention (plotted with factor scores, mean zero and standard deviation 1$)^{10}$ increases rapidly when Trust in Vendor increases. However, at high levels of PEEIM (mean + standard deviation), Repurchase Intention increases marginally as Trust in Vendor increases.

H2 was also supported: PEEIM positively moderates the relationship between Satisfaction with Vendor and Trust in Vendor $(\beta=0.165, \mathrm{t}=3.44, \mathrm{p}<0.001 \text {, one-tailed })^{11}$. We plotted this moderating effect in Figure 4. As expected, at high levels of PEEIM, Trust in Vendor increases rapidly as Satisfaction with Vendor increases. At low levels of PEEIM, Trust in Vendor does not increase regardless of the level of Satisfaction with Vendor.

\footnotetext{
${ }^{10}$ It is not possible to provide a single scale for Repurchase Intentions (RPI) as it is measured with three items, two of which have similar scales (1-7 Likert) but the third item has range from $0-100 \%$. The scale shown in the graph for RPI is that for latent variable score (varying from -1.5 SD to +1.5 SD)

${ }^{11}$ We also analyzed our research model using covariance-based SEM techniques (using AMOS 7.0 software). A Maximum Likelihood (ML) estimator provided path coefficients for the hypothesized paths that were consistent with those reported here (there were some marginal differences in the significance level of one control variable). Squared multiple correlations (an equivalent measure of $\mathrm{R}^{2}$ ) obtained using ML estimator were also comparable. Some of our control variables were ordinal; therefore, we also used the unweighted least squares (ULS) estimator to see whether or not the results obtained using component-based SEM were consistent. The results using ULS estimator were slightly different in the magnitude of coefficients, but the significance level remained the same and there were no substantial differences in the inferences. In addition, to test robustness of interaction effects, we used latent moderated structural equations (LMS) approach (Klein and Moosbrugger 2000) available in Mplus software. The results obtained using LMS approach were consistent with those reported in the paper.
} 


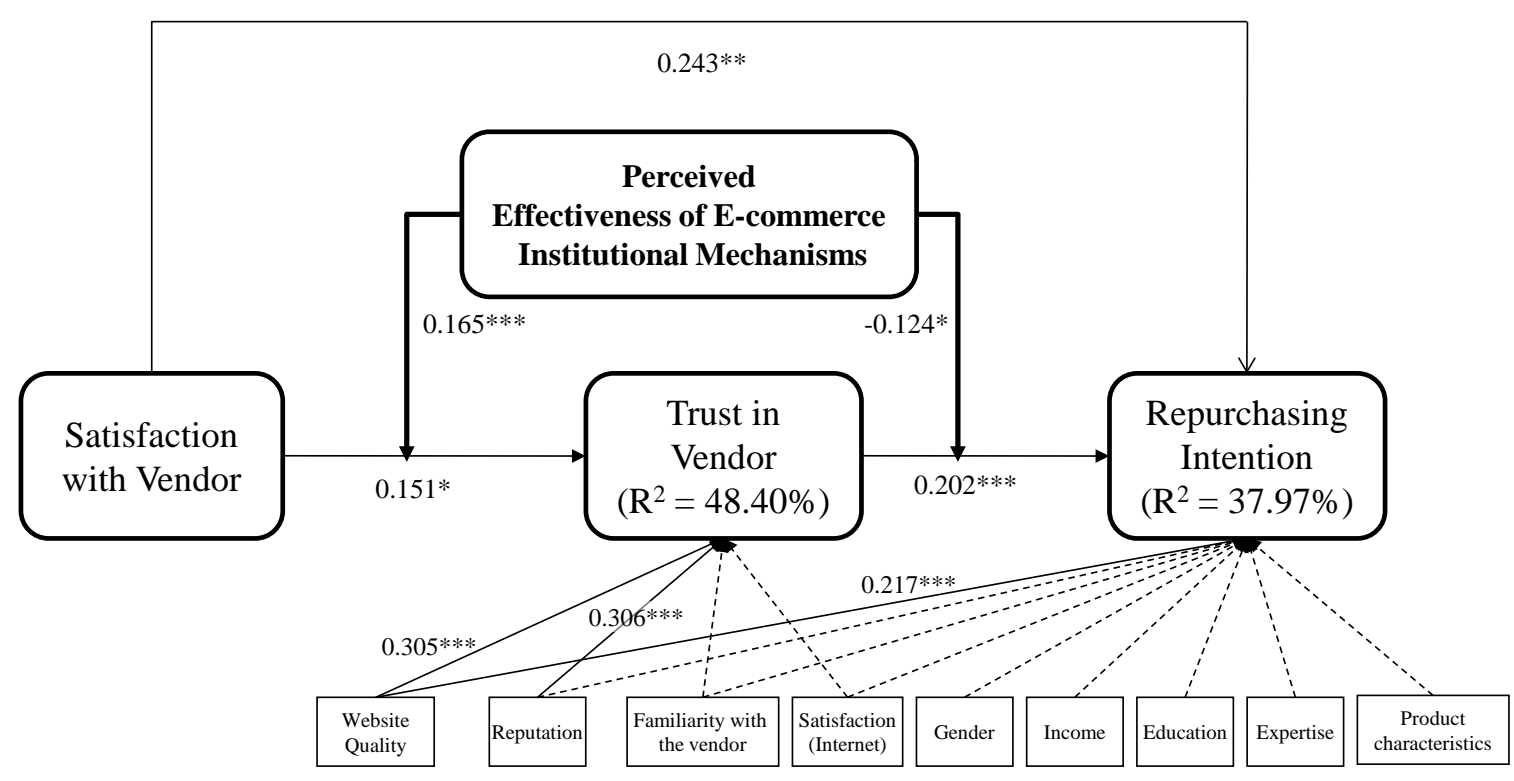

Note: Consistent with reporting moderating results direct paths PEEIM$>$ Trust in Vendor and PEEIM -> Repurchasing Intention were included

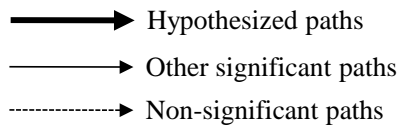

but not shown. Both these effects were non-significant

$* * *: \mathrm{p}<.001, * *: \mathrm{p}<.01, *: \mathrm{p}<.05$,

Figure 2 - Research Model Results

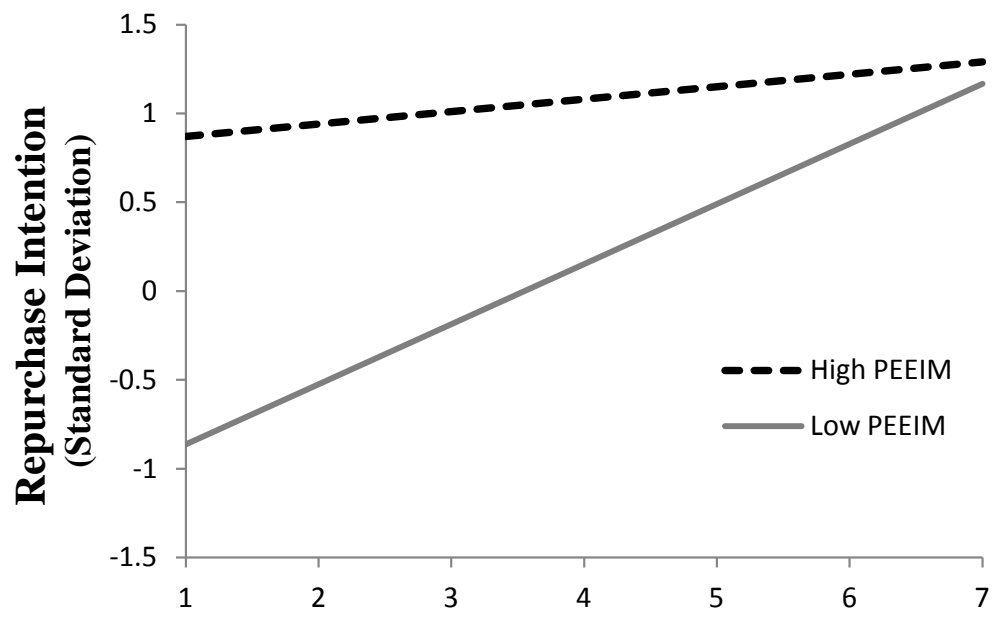

Trust in vendor

Figure 3 - The moderating effect of PEEIM on the relationship between trust and repurchase intention 


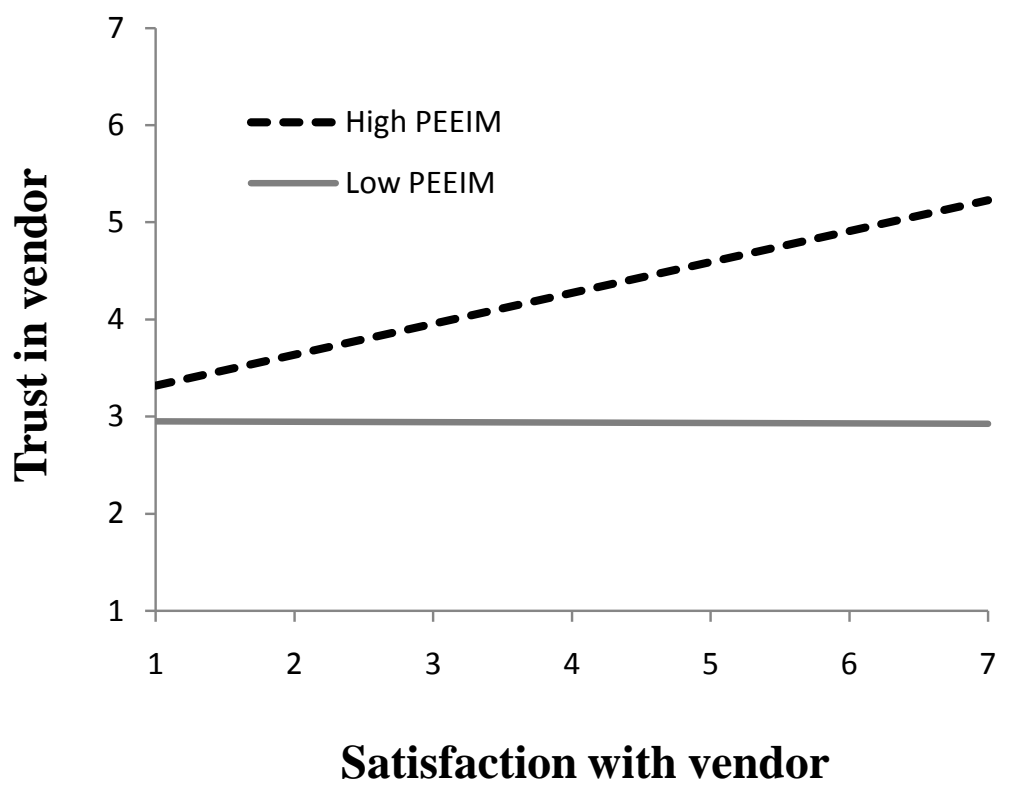

Figure 4 - The moderating effect of PEEIM on the relationship between satisfaction and trust

Consistent with our expectations, none of the main effects of PEEIM on Trust in Vendor $(\beta=0.048, \mathrm{t}=1.14)$ and Repurchase Intentions $(\beta=0.022, \mathrm{t}=0.40)$ were significant. In addition, and as expected, the relationship between Trust in Vendor and Repurchase Intention was positive and significant $(\beta=0.202, t=3.40)$ as was the relationship between Satisfaction with Vendor and Repurchase Intention ( $\beta=0.243, t=2.94)$. The relationship between Satisfaction with Vendor and Trust in Vendor was also positive and significant $(\beta=0.151, \mathrm{t}=2.21)$ when the interaction term with PEEIM was included. Furthermore, only two of the control variables had a significant effect on Trust in Vendor: Vendor Reputation and Perceived Website Quality. Only one control variable, Perceived Website Quality, had a significant effect on Repurchase Intention ${ }^{12}$.

\footnotetext{
${ }^{12}$ To ensure that our results did not confound with vendor-specific institutional mechanisms, we included two measures (for online security and customer guarantee, respectively) in our survey to check if the effect of vendorspecific mechanisms was salient to the respondents. We asked in the survey: (1) "Did the vendor have a "confidenceinspiring" security mark (i.e. BBBOnline, TRUSTe, VeriSign etc) on its Web site?, and (2) "Did the vendor have a customer guarantee policy on its Web site?”. Out of 362 valid responses, 226 did not check security marks while 251 did not know or check the customer guarantee policy. These results are likely due to the reduced importance of vendorspecific institutional mechanisms in the online repurchase context, as suggested by McKnight et al. (1998a). These results are also consistent with previous research indicating that customers do not often notice or care about the vendor-
} 
To determine whether the significant moderating effects are substantive, R-square changes resulting from the interaction effects should be examined (Carte and Russell 2003), specifically through the F-test (Cohen and Cohen 1983). Appendix-II provides the F-test and the effect size results by running three nested (hierarchical) models. Model 1 only includes control variables. Model 2 adds main effects of independent variables to Model 1. Model 3 adds interaction effects of PEEIM to Model 2.

The results showed that Trust in Vendor significantly increased $\mathrm{R}^{2}$ of Repurchase Intention by 7.49\% ( $F=20.61, p<0.05)$, indicating a medium effect size $\left(f^{2}=0.12\right)$. The interaction effect of PEEIM with Trust in Vendor significantly increased $\mathrm{R}^{2}$ of Repurchase Intention by $1.57 \%$ ( $F=8.83$, $\mathrm{p}<0.05)$, indicating a small effect size $\left(\mathrm{f}^{2}=0.03\right)^{13}$. The results also showed that Satisfaction with Vendor did not significantly affect Trust in Vendor, nor did it increase $\mathrm{R}^{2}$, when its interaction term with PEEIM was not included. When the interaction effect of PEEIM with Satisfaction with Vendor was included, $\mathrm{R}^{2}$ of Trust in Vendor was significantly increased by $2.7 \%$ ( $F=18.58$, $\mathrm{p}<0.05)$, indicating a small-to-medium effect size $\left(\mathrm{f}^{2}=0.05\right)$. Thus, the F-test results showed that both of the interaction effects increased $\mathrm{R}^{2}$ significantly, confirming the significance of the

specific trust logos and seals of approval, even if they are from the third party (Corritore et al. 2003; Nielsen et al. 2000). We ran the research model again with the subset who did not know/did not check these vendor-specific institutional mechanisms (and therefore teasing out any possible effects by vendor-specific mechanisms), and the statistical results about PEEIM remain the same, suggesting that our research model holds for respondents not affected by vendor-specific mechanisms.

13 The conventional value for effect size $\left(\mathrm{f}^{2}\right)$ proposed by Cohen (1988) are 0.02 (small), 0.15 (medium), and 0.35 (high). Based on this, the effect sizes of our hypothesized relationships are relatively small. However, it is important to note that these were general guidelines for any effects and not specific to interaction effects. Past studies have found that the size of the interaction effect was generally small in most empirical studies (Chin et al. 2003; Weill and Olson 1989) and that an effect size of 0.02 is regarded as an optimistic interaction effect (Aguinis 2004). The commonly held reason for low effect size is the low reliability of the product terms (Cohen et al. 2003; Jaccard and Turrisi 2003) not the importance of theoretical model relationships (Chin et al. 2003; Lowry et al. 2009). Indeed, a literature review on research articles representing great theoretical advancements over the past three decades indicates that the median effect size for the interactions effects is about 0.002, while the average is about 0.005 (Aguinis et al. 2005). Likewise, our literature review on MISQ and ISR also reveals that it is not uncommon to report small to moderate effect sizes for moderating relationships. For example, Kim et al. (2005), Majchrzak et al. (2005), and Angst and Agarwal (2009) also reported significant moderating effects with R-square changes about $1 \%$. In comparison, the effect sizes of the interaction effects in our study are preferable. 
moderating effects (Carte and Russell 2003). For better visual clarity, these interaction effects are presented as a 3D graph in the Appendix-III.

\section{Discussion, Implications and Future Research}

\subsection{Research Implications}

Although the focus of our study, e-commerce institutional mechanisms, is not new to the ecommerce literature, prior related e-commerce research has only examined the role of institutional mechanisms in the context of initial online purchase (McKnight et al. 2002a; McKnight et al. 2002b; Pavlou and Gefen 2004; Pennington et al. 2003). Relevant studies in the context of repeat

online purchase are rare, possibly because institutional mechanisms, as a second-hand source of trust production, are not presumed to be relevant when customers possess first-hand information about the online vendor (McKnight et al. 1998). The present study adds new understanding of ecommerce institutional mechanisms by defining the construct PEEIM and differentiating it from existing similar concepts in terms of its articulated focus on general perception and risk mitigation. Our examination of its role in relationships involving satisfaction, trust and online repurchase intention reveals several important research findings.

First and foremost, our study confirms that PEEIM negatively moderates the relationship between Trust in Vendor and Repurchase Intention, such that the positive effect of Trust in Vendor on Repurchase Intention is weaker when PEEIM is higher. This result adds to the e-commerce literature by addressing the call for identifying important boundary conditions for the relationship between trust and online shopping behavior (Gefen et al. 2008). Gefen et al. (2008) properly pointed out that the existing literature has largely ignored the conditions under which trust has a varying effect on behavioral intentions and thus represents an oversimplification of the context in which trust operates. By drawing on the organizational theory of trust (Mayer et al. 1995) our 
findings advance our understanding of the conditional effect of trust by explicitly specifying the e-commerce institutional context as an important boundary condition to assess how trust influences online repurchase intention. With this new insight our study provides a plausible explanation to the finding that trust has a much less important, albeit still significant, effect on customer retention in some studies (e.g. Ribbink et al., 2004) relative to others (e.g., Flavian et al. 2006; Gefen 2002; Li et al. 2006; Qureshi et al. 2009). Our findings suggest that cementing trust in an online vendor might not be as universally important as we once believed it to be if customers perceive that effective e-commerce institutional mechanisms are in place.

Second, our study finds that PEEIM positively moderates the relationship between Satisfaction with Vendor and Trust in Vendor, such that the effect of satisfaction on trust becomes stronger when PEEIM is higher. This moderating effect implies that satisfaction can be an important source of trust production only under the condition of high, but not low PEEIM. In other words, people may be more hesitant to apply their past positive experiences with a vendor to form their expectations of the vendor's future behavior (trust) if there is a perceived lack of effective institutional mechanisms in place. Indeed, our interaction plot (figure 4) does suggest that satisfaction could have an insignificant effect on trust when PEEIM is very low.

This finding is an important contribution to our scholarly understanding of how trust is evaluated in existing online relationships. The literature has documented that, in general, positive outcomes of prior exchange would enhance the trustor's perceptions of the trustee (Mayer et al. 1995), and in particular, customers satisfied with prior exchange processes with an online vendor will be more likely to trust the vendor (Flavian et al. 2006; Li et al. 2006; Ribbink et al. 2004). However, to the best of our knowledge, the existing literature has not considered potential contextual conditions in which trust is evaluated, despite Mayer et al.'s (1995) suggestion that a 
clear understanding of trust in a trustee necessitates an understanding of the context in which trust operates. Our study is among the first to address this theoretical gap in the e-commerce literature by theorizing and empirically verifying the important role of the e-commerce institutional infrastructure in affecting experience-based evaluations of trust in existing online exchange relationships.

Also, this finding advances our understanding of trust production mechanisms. Trust production through Satisfaction with Vendor is a mechanism known as the process-based source of trust production, whereas institutional structures have long been considered as an alternative source of trust production (Zucker 1986). Numerous studies have examined their respective direct effects on trust (Flavian et al. 2006; Kim et al. 2004; Li et al. 2006; Ribbink et al. 2004) with little research recognizing that different sources of trust production could complement each other. In essence, this finding adds to the existing literature by demonstrating that an institution-based trust lever (PEEIM) and a process-based trust lever (Satisfaction with Vendor) can interact to produce an additional influence on customer trust in an online vendor.

Taking these two key findings together, our study reveals an interesting paradoxical effect of e-commerce institutional mechanisms on the importance (i.e. outcomes) and evaluation (i.e. antecedents) of trust in existing online exchange relationships. On the one hand, a positive (high level) perception of e-commerce institutional mechanisms can ease the process of evaluating an online vendor's trustworthiness; whilst on the other hand diminishes the importance of established trust in repurchase intention situations. In other words, when trust is easier to develop through successful past transactions (under the context of effective e-commerce institutional mechanisms), its importance in repurchase situations weakens. 
This paradoxical result helps reveal the conditions under which trust in a vendor can be qualified as a source of genuine competitive advantage in the online context. In the early stages of e-commerce, trust was believed to be a source of competitive advantage for online vendors (Pavlou and Gefen 2004) due to its inherent ability to reduce the cost of monitoring online transactions. Our study argues that this is only true when PEEIM is not effective. This implies that promoting trust and trustworthiness may no longer be a sufficient and unique competitive advantage over competitors when PEEIM is effective, because in this context its role in the repurchase episodes is demoted to secondary importance. Consequently, its strategic impact on differentiating vendor performance (e.g. customer retention) from those of competitors becomes less important. This view is largely consistent with strategy theorists who suggest that trust can lead to competitive advantage only when it is valuable, rare and difficult to build and replicate by competitors (Barney and Hansen 1994). The present study helps confirm such conditions.

This study also makes an empirical contribution. McKnight et al. (1998) argued that the effect of institutional mechanisms on trusting beliefs and behavior would not hold in existing exchange relationships, such as the case of online repurchase, because the first-hand information accumulated through prior direct interactions with the vendor would mask the effect of institutional factors. This study is one of the first to examine this assertion and it is interesting to observe in our data that the direct relationship between PEEIM and Repurchase Intention is indeed not significant which is consistent with the prediction made by McKnight et al. (1998). Similarly, the non-significant direct relationship between PEEIM and Trust in Vendor in our data is also consistent with McKnight et al.'s (1998) prediction. Although technically it would be very difficult, if not impossible, to verify the existence of these two null relationships in the absence of a sufficiently large sample size and a large amount of replication in various contexts (Cortina and 
Folger 1998; Greenwald 1993), our empirical results at least makes an early move towards providing preliminary evidence for the theoretical deduction made by McKnight et al. (1998). Future research could investigate this more closely.

\subsection{Practical Implications}

Our study has managerial implications for both online vendors and public policy makers. First, our study recommends to online vendors that whilst it remains important for them to focus on building trust with customers, they should more strategically allocate their trust-building resources according to the level of existing e-commerce institutional mechanisms (e.g. the maturity level of online credit card guarantees, escrow services and privacy protection services). They could first survey (potential) online customers to assess their PEEIM. If they operate in an e-commerce institutional environment that is perceived relatively ineffective, they should commit more resources to building trust with customers, despite the evident challenges of doing so. Alternatively, online vendors may save trust maintenance costs by strategically targeting a segment of online customers who perceive themselves as residing in a relatively effective e-commerce institutional environment. In such an environment, building trust with online customers remains important but is not as crucial as it is elsewhere. To the extent that PEEIM is expected to vary more significantly across regions, this set of recommendations is particularly relevant to firms operating e-commerce in multiple regions, such as multinational firms.

Second, with our findings, Internet policy makers should be advised to commit themselves to (1) building a more effective institutional infrastructure for the entire e-commerce environment, and (2) communicating the risk-mitigation value of the e-commerce institutional infrastructure to the Internet public. A perceivably safer e-commerce environment could help make trust building 
a less difficult mandate for online vendors to embark upon, thereby contributing to the prosperity of e-commerce in their regions.

\subsection{Limitations and Future Research Directions}

Future research can take this study further by addressing several limitations of our study. First, our sample was drawn from university personnel. While the university personnel were all online customers with experience in purchasing products online, future research can take this investigation further by drawing research subjects from a more diverse population.

Second, as this study exclusively focuses on the general perception of institutional mechanisms, we only theoretically differentiate the effect of PEEIM from vendor-specific mechanisms, laying bare the possibility that the presence of vendor-specific mechanisms may outweigh PEEIM. Although our control variables partially mitigate this concern by capturing respondents' attention to selected vendor-specific mechanisms, further research could and should empirically examine PEEIM against more local, specific institutional mechanisms.

Third, the suitability of the Internet as a shopping medium largely depends on the characteristics of the product sought. Some products are more conveniently bought in traditional shopping environments, while others such as software, airline tickets and hotel reservations are easier to buy online. Thus, product category may act as a moderating variable and should be investigated in future research.

Furthermore, the wording of our third survey item for PEEIM may have induced different interpretations by the respondents. We mitigated this concern in two ways. First, as mentioned earlier, we explicitly grouped this item with others measuring the general perception of the ecommerce environment in the survey, separating it from those measuring vendor-specific perceptions and thus reducing the likelihood of respondents associating this item with vendor- 
specific mechanisms. Second, we tested the measurement model for PEEIM, which exhibited satisfactory reliability and validity. Also, the empirical results of the model did not change in significance levels when the third PEEIM item was removed. Even with these robustness checks, future research should consider improving the PEEIM measures by developing additional items.

In addition, the moderating relationships advanced in our study yield a significant, albeit limited, increase in explained variance. Whilst even small interaction effects using the productindicator approach can suggest important moderating relationships (Chin et al. 2003; Lowry et al. 2009), the interpretation of these results should still be made cautiously. Since the significant moderation effects indicate credible empirical support for examining moderation in the theory we advance, future research should test these effects in other conditions.

Moreover, the recall method used in our survey might induce memory recall bias. While proper measures recommended in the memory literature have been taken in the survey design to minimize the concern, future research could consider replicating the study with alternative methods (e.g. experiments). Also, more objective measures such as repeated purchase behavior may be used as an additional dependent variable to improve the predictability of our model. The current research model could also be extended by modeling the well-established risk-reduction effect of trust under different e-commerce institutional environments.

Finally, we suggest that future research may follow a similar approach to investigating the "unexplored area” shown in Table 2, where negative risk framing is applied to vendor-specific institutional mechanisms, and attempt to quantify the practical impact of this framing effect in the e-commerce context. 


\section{Conclusion}

This study extends our understanding of the role of e-commerce institutional mechanisms in the online repurchase context by introducing the construct of PEEIM and its moderating roles in the relationships between satisfaction, trust and online customer repurchase intention. We found that PEEIM negatively moderates the relationship between trust and customer repurchase intention yet positively moderates the relationship between customer satisfaction and trust in an online vendor. These research findings not only address the call for specifying the boundary conditions under which customer trust affects online transaction behavior but also enhances our understanding of how different trust production mechanisms can reinforce each other to build stronger trust in an online vendor. Collectively, these findings illustrate the paradoxical role of ecommerce institutional mechanisms and set a starting point for future research to further explore the effect of institutional mechanisms in e-commerce environments. 


\section{References}

Abelson, R.P., Aronson, E., McGuire, W., Newcomb, W.J., Rosenberg, M.J., and Tannenbaum, P.H. 1968. The Theories of Cognitive Consistency: A Sourcebook. Chicago: Rand-McNally.

Aguinis, H. 2004. Moderated Regression. New York: Guilford.

Aguinis, H., Beaty, J.C., Boik, R.J., and Pierce, C.A. 2005. "Effect Size and Power in Assessing Moderating Effects of Categorical Variables Using Multiple Regression: A 30- Year Review," Journal of applied Psychology (90:1), pp. 94-107.

Akerlof, G. 1970. "The Market for 'Lemons': Quality Uncertainty and the Market Mechanism," Quarterly Journal of Economics (84:3), pp. 488-500.

Andaleeb, S.S. 1996. "An Experimental Investigation of Satisfaction and Commitment in Marketing Channels: The Role of Trust and Dependence," Journal of Retailing (72:1), pp. 77-93.

Anderson, J.C., and Gerbing, D.W. 1988. "Structural Equation Modeling in Practice: A Review and Recommended Two-Step Approach," Psychological Bulletin (103:3), p. 411.

Angst, C.M., and Agarwal, R. 2009. "Adoption of Electronic Health Records in the Presence of Privacy Concerns: The Elaboration Likelihood Model and Individual Persuasion," MIS Quarterly (33:2), pp. 339-370.

Armstrong, J., and Overton, T. 1977. "Estimating Non-Response Bias in Mail Surveys," Journal of Marketing Research (14:3), pp. 396-402.

Bagozzi, R.P., and Silk, A.J. 1983. "Recall, Recognition, and the Measurement of Memory for Print Advertisements," Marketing Science (2:2), pp. 95-134.

Balabanis, G., and Reynolds, N.L. 2001. "Consumer Attitudes Towards Multichannel Retailers’ Web Sites: The Role of Involvement, Brand Attitude, Internet Knowledge and Visit Duration," Journal of Business Strategies (18:2), pp. 105-131.

Ball, D., Coelho, P.S., and A., M. 2006. "The Role of Communication and Trust in Explaining Customer Loyalty: An Extension to the Esci Model,," European Journal of Marketing (38:9/10), pp. 1272-1293.

Barber, B. 1983. The Logic and Limits of Trust. Rutgers University Press.

Barclay, D., and Higgins, C. 1995. "The Partial Lease Squares (Pls) Approach to Causal Modeling: Personal Computer Adoption and Use as an Illustration," Technology Studies (2:2), pp. 285309.

Barney, J.B., and Hansen, M.H. 1994. "Trustworthiness as a Source of Competitive Advantage," Strategic Management Journal (15), pp. 175-190.

Bauer, H.H., Grether, M., and Leach, M. 2002. "Building Customer Relations over the Internet," Industrial Marketing Management (31), pp. 155-163.

Berry, L., and Parasuram, A. 1991. Marketing Services: Competing through Quality. Reading, MA: Addison-Wesley.

Bradach, J.L., and Eccles, R.G. 1989. "Price, Authority, and Trust: From Ideal Types to Plural Forms," Annual Review of Sociology (15), pp. 97-118.

Bradburn, N.M. 2004. "Understanding the Question-Answer Process," Survey Methodology (30:1), pp. 5-15.

Cacioppo, J.T., and Berntson, G.G. 1994. "Relationships between Attitudes and Ealuative Space: A Critical Review, with Emphasis on the Separability of Positive and Negative Substrats," Psychological Bulletin (115:3), pp. 401-423.

Carmines, E.G., and Zeller, R.A. (eds.). 1979. Reliability and Validity Assessment. Beverly Hills, CA: Sage.

Carte, T.A., and Russell, C.J. 2003. "In Pursuit of Moderation: Nine Common Errors and Their Solutions," MIS Quarterly (27:3), pp. 479-501. 
Chakraborty, G., Lala, V., and Warren, D. 2002. "An Empirical Investigation of Antecedents of B2b Websites’ Effectiveness," Journal of Interactive Marketing (16:4), pp. 51-72.

Chin, W.W., Marcolin, B.L., and Newsted, P.R. 2003. "A Partial Least Squares Latent Variable Modeling Approach for Measuring Interaction Effects: Results from a Monte Carlo Simulation Study and an Electronic-Mail Emotion/Adoption Study," Information Systems Research (14:2), pp. 189-217.

Cohen, J. 1988. Statistical Power Analysis for the Behavioral Sciences. HillsDale, NJ: Lawrence Erlbaum.

Cohen, J., and Cohen, P. 1983. Applied Multiple Regression/Correlation Analyses for the Behavioral Sciences. Hillsdale, NJ: Lawrence Erlbaum.

Cohen, J., Cohen, P., West, S.G., and Aiken, L.S. 2003. Applied Multiple Regression/Correlation Analysis for the Behavioral Sciences. Mahwah, NJ:

Corritore, C.L., Kracher, B., and Wiedenbeck, S. 2003. "On-Line Trust: Concepts, Evolving Themes, a Model," International Journal of Human-Computer Studies (58:6), pp. 737-758.

Cortina, J., and Folger, R. 1998. "When Is It Acceptable to Accept a Null Hypothesis: No Way, Jose?," Organizational Research Methods (1:3), p. 334.

Crosby, L.A., and Stevens, N. 1987. "Effects of Relationship Marketing on Satisfaction, Retention and Prices in the Life Insurance Industry," Journal of Marketing Research (24:404-411).

de Vaus, D.A. 1995. Surveys in Social Research, (4th ed.). St. Leonards, NSW, Australia: Allen \& Unwin.

Doney, P.M., and Cannon, J.P. 1997. "An Examination of the Nature of Trust in Buyer-Seller Relationships," Journal of Marketing:61), pp. 35-51.

Doorn, J.v., and Verhoef, P.C. 2008. "Critical Incidents and the Impact of Satisfaction on Customer Share," Journal of Marketing (72), pp. 123-142.

Einwiller, S. 2003. "When Reputation Engenders Trust: An Empirical Investigation in Business to Consumer Electronic Commerce," Electronic Markets (13:3), pp. 196-209.

Flavian, C., Guinaliu, M., and Gurrea, R. 2006. "The Role Played by Perceived Usability, Satisfaction and Consumer Trust on Website Loyalty," Information \& Management (43), pp. $1-14$.

Fornell, C., and Larcker, D.F. 1981. "Evaluating Structural Equation Models with Unobservable Variables and Measurement Error," Journal of Marketing Research (18:1), p. 39.

Fukuyama, T. 1995. Trust: The Social Virtues and the Creation of Prosperity. New York: The Free Press.

Ganesan, S. 1994. "Determinants of Long-Term Orientation in Buyer - Seller Relationships," Journal of Marketing (58:2), pp. 1-19.

Garbarino, E., and Johnson, M.S. 1999. "The Different Roles of Satisfaction, Trust, and Commitment in Customer Relationships," Journal of Marketing (63:2), pp. 70-87.

Garbarino, E., and Lee, O.F. 2003. "Dynamic Pricing in Internet Retail: Effects on Consumer Trust," Psychology and Marketing (20:6), pp. 495-513.

Gardial, S.F., Clemons, D.S., Woodruff, R.B., and Schumann, D.W. 1994. "Comparing Consumers' Recall of Prepurchase and Postpurchase Product Evaluation Experiences," Journal of Consumer Research (20:4), pp. 548-560.

Gefen, D. 2002. "Customer Loyalty in E-Commerce," Journal of the Association for Information Systems (3:2).

Gefen, D., Benbasat, I., and Pavlou, P. 2008. "A Research Agenda for Trust in Online Environments," Journal of Management Information Systems (24:4), pp. 275-286.

Gefen, D., Karahanna, E., and Straub, D.W. 2003. "Trust and Tam in Online Shopping: An Integrated Model," MIS Quarterly (27:1), March, pp. 51-90. 
Gefen, D., and Pavlou, P. 2006. "The Moderating Role of Perceived Regulatory Effectiveness of Online Marketplaces on the Role of Trust and Risk on Transaction Intentions," International Conference on Information Systems).

Grabner-Krauter, S., and Kaluscha, E.A. 2003. "Empirical Research in on-Line Trust: A Review and Critical Assessment," International Journal of Human-Computer Studies (58), pp. 783-812.

Greenwald, A. 1993. "Consequences of Prejudice against the Null Hypothesis," in A Handbook for Data Analysis in the Behavioral Sciences: Methodological Issues. pp. 419-448.

Hirshleifer, J., and Riley, J.G. 1979. "The Analytics of Uncertainty and Information: An Expository Survey.," Journalof Economic Literature (17:1374-1421).

Holmes, J.G. 1991. "Trust and the Appraisal Process in Close Relationships," Advances in Personal Relationships (2), pp. 57-104.

Jaccard, J., and Turrisi, R. 2003. Interaction Effects in Multiple Regression. Thousands Oak, CA: Sage.

Jamal, A., and Naser, K. 2002. "Customer Satisfaction and Retail Bankingan Assessment of Some of the Key Antecedents of Customer Satisfaction in Retail Banking. International Journal of Bank Marketing 20(4), 146-160.," International Journal of Bank Marketing (20:4), pp. 146160.

Jarvenpaa, S.L., and Tractinsky, N. 1999. "Consumer Trust in an Internet Store: A Cross-Cultural Validation," Journal of Computer Mediated communication (5:2), pp. 1-35.

Jarvenpaa, S.L., Tractinsky, N., and Vitale, M. 2000. "Consumer Trust in an Internet Store," Information Technology and Management (1:1-2), p. 45.

Johnson, C.a.H., P. 2008. "Web Buyers and Their Expectations Grow up - Experienced Web Buyers Are Becoming the New Mainstream.," Forrest Research, accessed April 2008, http://www.forrester.com/Research/PDF/0,5110,45462,00.pdf).

Jöreskog, K.G., and Wold, H. 1982. "The Ml and Pls Techniques for Modeling with Latent Variables: Historical and Comparative Aspects," in Systems under Indirect Observation: Causality, Structure, Prediction, K.G. Jöreskog and H. Wold (eds.). Amsterdam: North Holland, pp. 263-270.

Kahneman, D., and Tversky, A. 1979. "Prospect Theory: An Analysis of Decisions under Risk," Econometrica (47), March, pp. 263-291.

Kennedy, M.S., Ferrell, L.K., and LeClair, D.T. 2001. "Consumers' Trust of Salespeople and Manufacturer: An Empirical Study," Journal of Business Research (51), pp. 73-86.

Kenny, D.A., and Judd, C.M. 1984. "Estimating the Nonlinear and Interactive Effects of Latent Variables," Psychological Bulletin (96:1), pp. 201-210.

Kerlinger, F.N. 1973. Foundations of Behavioral Research, (2nd Edition ed.). New York: Holt, Rinehart \& Winston.

Kim, D., and Benbasat, I. 2006. "The Effects of Trust-Assuring Arguments on Consumer Trust in Internet Stores: Application of Toulmin's Model of Argumentation," Information Systems Research (17:3), pp. 286-300.

Kim, D., and Benbasat, I. 2009. "Trust-Assuring Arguments in B2c E-Commerce: Impact of Content, Source, and Price on Trust," Journal of Management Information Systems (26:3), pp. 175206.

Kim, D.J., Ferrin, D.L., and Rao, H.R. 2009. "Trust and Satisfaction, Two Stepping Stones for Successful E-Commerce Relationships: A Longitudinal Exploration," Information Systems Research (20:2), pp. 237-257.

Kim, H.-W., Xu, Y., and Koh, J. 2004. "A Comparison of Online Trust Building Factors between Potential Customers and Repeat Customers," Journal of the Association for Information Systems (5:10), pp. 392-420. 
Kim, S.S. 2009. "The Integrative Framework of Technology Use: An Extension and Test," MIS Quarterly (33:3), pp. 513-537.

Kim, S.S., Malhotra, N.K., and Narasimhan, S. 2005. "Two Competing Perspectives on Automatic Use: A Theoretical and Empirical Comparison," Information Systems Research (16:4), pp. 418-432.

Klein, A., and Moosbrugger, H. 2000 "Maximum likelihood estimation of latent interaction effects with the LMS method," Psychometrika (65:4), pp 457-474.

Lewicki, R.J., and Bunker, B.B. 1995. "Trust in Relationships: A Model of Trust Development and Decline," in Conflict, Cooperation and Justice, B.B. Bunker and J.Z. Rubin (eds.). JosseyBass, San Francisco: pp. 133-173.

Lewis, J.D., and Weigert, A. 1985. "Trust as a Social Reality," Social Forces (63:4), pp. 967-985.

Li, D., Browne, G.J., and Wetherbe, J.C. 2006. "Why Do Internet Users Stick with a Specific Web Site? A Relationship Perspective," International Journal of Electronic Commerce (10:4), pp. 105-141.

Lim, K., Sia, C.L., Lee, M.K.O., and Benbasat, I. 2006. "How Do I Trust You Online, and If So, Will I Buy? An Empirical Study on Designing Web Contents to Develop Online Trust," Journal of Management Information Systems (23:2), pp. 233-266.

Lindell, M., and Whitney, D. 2001. "Accounting for Common Method Variance in Cross-Sectional Research Designs," Journal of Applied Psychology (86:1), pp. 114-121.

Liu, B.Q., and Goodhue, D. 2012. "Two Worlds of Trust for Potential E-Commerce Users: Humans as Cognitive Misers," Information Systems Research (forthcoming).

Lohmöller, J. 1982. "An Overview of Latent Variables Path Analysis," Annual Meeting of the American Educational Research Association, New York.

Louis, M.R., and Sutton, R.I. 1991. "Switching Cognitive Gears: From Habits of Mind to Active Thinking," Human Relations (44:1), pp. 55-76.

Lowry, P.B., Romano, N.C., Jenkins, J.L., and Guthrie, R.W. 2009. "The Cmc Interactivity Model: How Interactivity Enhances Communication Quality and Process Satisfaction in Lean-Media Groups," Journal of Management Information Systems (26:1), pp. 159-200.

Luhmann, N. 1979. Trust and Power. London: John Wiley and Sons.

MacKenzie, S. B., Podsakoff, P. M., and Podsakoff, N. P. 2011 "Construct measurement and validation procedures in MIS and behavioral research: Integrating new and existing techniques," MIS Quarterly (35:2), pp 293-334.

Majchrzak, A., Malhotra, A., and John, R. 2005. "Perceived Individual Collaboration Know-How Development through Information Technology"Cenabled Contextualization: Evidence from Distributed Teams," Information Systems Research (16:1), pp. 9-27.

Mayer, R.C., Davis, J.H., and Schoorman, F.D. 1995. "An Integrative Model of Organizational Trust," Academy of Management Review (20:3), pp. 709-734.

McKnight, D., and Chervany, N. 2002. "What Trust Means in E-Commerce Customer Relationships: An Interdisciplinary Conceptual Typology," International Journal of Electronic Commerce (6:2).

McKnight, D., Choudhury, V., and Kacmar, C. 2002a. "Developing and Validating Trust Measures for E-Commerce: An Integrative Typology," Information Systems Research (13:3), pp. 334359.

McKnight, D., Choudhury, V., and Kacmar, C. 2002b. "The Impact of Initial Consumer Trust on Intentions to Transact with a Web Site: A Trust Building Model," Journal of Strategic Information Systems (22), pp. 297-323.

McKnight, D. H., Choudhury, V. \& Kacmar, C. 2004. "Shifting Factors and the Ineffectiveness of Third Party Assurance Seals: A Two-Stage Model of Initial Trust in an E-Vendor.” Electronic Markets, 14(3), 252-266) 
McKnight, D., Cummings, L.L., and Chervany, N. 1998. "Initial Trust Formation in New Organizational Reationships," Academy of Management Review (23:3), pp. 473-490.

Moore, G.C., and Benbasat, I. 1991. "Development of an Instrument to Measure the Perceptions of Adopting an Information Technology Innovation," Information Systems Research (2:3), pp. 192-222.

Nielsen, J., Molich, R., Snyder, C., and Farrell, S. 2000. E-Commerce User Experience: Trust. Fremont, CA: Nielsen NormanGroup.

Nunnally, J.C., and Bernstein, I.H. 1994. Psychometric Theory, (3rd ed.). New York: McGraw-Hill.

Oliver, R., and Swan, J. 1989. "Consumer Perceptions of Interpersonal Equity and Satisfaction in Transactions: A Field Survey Approach," Journal of Marketing (53), pp. 21-35.

Oliver, R.L. 1999. "Whence Customer Loyalty?," Journal of Marketing (63), pp. 33-44.

Oswald, M.E., and Fuchs, T. 1998. "Readiness to Trust in Complex Situations," Swiss Journal of Psychology (57:4), pp. 248-254.

Otim, S., and Grover, V. 2006. " An Empirical Study on Web-Based Services and Customer Loyalty," European Journal of Information Systems (15), pp. 527 - 541.

Pavlou, P., and Fygenson, M. 2006. "Understanding and Predicting Electronic Commerce Adoption: An Extension of the Theory of Planned Behavior," MIS Quarterly (30:1), pp. 115-143.

Pavlou, P.A., and Gefen, D. 2004. "Building Effective Online Marketplaces with Institution-Based Trust," Information Systems Research (15:1), Mar, pp. 37-59.

Pennington, R., Wilcox, D., and Grover, V. 2003. "The Role of System Trust in Business-toConsumer Transactions," Journal of Management Information Systems (20:3), pp. 197-226.

Podsakoff, P., MacKenzie, S., Lee, J., and Podsakoff, N. 2003. "Common Method Biases in Behavioral Research: A Critical Review of the Literature and Recommended Remedies," Journal of Applied Psychology (88:5), pp. 879-903.

Podsakoff, P.M. 1986. "Self-Reports in Organizational Research: Problems and Prospects," Journal of Management (12:4), pp. 531-544.

Qureshi, I., and Compeau, D. 2009. "Assessing between-Group Differences in Information Systems Research: A Comparision of Covariance- and Component-Based Sem," MIS Quarterly (33:1), pp. 197-214.

Qureshi, I., Fang, Y., Ramesy, E., McCole, P., Ibboston, P., and Compeau, D. 2009. "Understanding Online Customer Repurchasing Intention and the Mediating Role of Trust - an Empirical Investigation in Two Developed Countries," European Journal of Information Systems (18:3), pp. 205-222.

Ribbink, D., van Riel, A.C.R., Liljander, V., and Streukens, S. 2004. "Comfort Your Online Customer: Quality, Trust and Loyalty on the Internet," Managing Service Quality (14:6), pp. 446-456.

Richardson, H., Simmering, M., and Sturman, M. 2009. "A Tale of Three Perspectives: Examining Post Hoc Statistical Techniques for Detection and Correction of Common Method Variance," Organizational Research Methods (12:3), p. 762.

Schlosser, A.E., White, T.B., and Lloyd, S.M. 2006. "Converting Web Site Visitors into Buyers: How Web Site Investment Increases Consumer Trusting Beliefs and Online Purchase Intentions," Journal of Marketing (70), pp. 133-148.

Shapiro, S.P. 1989. "The Social Control of Impersonal Trust," The American Journal of Sociology (93:3), pp. 623-658.

Sitkin, S.B., and Pablo, A.L. 1992. "Reconceptualizing the Determinants of Risk Behavior," Academy of Management Review (17:1), pp. 9-38.

Sitkin, S.B., and Roth, N.L. 1993. "Explaining the Limited Effectiveness of Legalistic "Remedies" for Trust/Distrust," Organization Science (4:367-392). 
Spencer, B. 1999. "An Examination of the Relationship Betweeb Corporate Image and Sponsorship.,". University of Otago).

Srinivasana, S.S., R., A., and Ponnavolub, K. 2002. "Customer Loyalty in E-Commerce: An Exploration of Its Antecedents and Consequences," Journal of Retailing (78), pp. 41-50.

Stewart, K.J. 2003. "Trust Transfer in World Wide Web," Organization Science (14:1), pp. 5-17.

Sudman, S., and Bradburn, N.M. 1973. "Effects of Time and Memory Factors on Response in Surveys," Journal of the American Statistical Association (68), pp. 805-815.

Tulving, E. 1983. Elements of Episodic Memory. Oxford Oxfordshire and New York: Clarendon Press.

Tversky, A., and Kahneman, D. 1981. "The Framing of Decisions and the Psychology of Choice," Science (211:4481), pp. 453-458.

Van der Heijden, H., Verhagen, T., and Creemers, M. 2003. "Understanding Online Purchase Intentions: Contributions from Technology and Trust Perspectives," European Journal of Information Systems (12), pp. 41-48.

Van Slyke, C., Comunale, C., and Belanger, F. 2002. " Gender Differences in Perceptions of WebBased Shopping," Communications of the ACM (45:8), pp. 82-86.

Vance, A., Elie-Dit-Cosaque, C., and Straub, D.W. 2008. "Examining Trust in Information Technology Artifacts: The Effects of System Quality and Culture.," Journal of Management Information Systems (24:4), pp. 73-100.

Weill, P., and Olson, M.H. 1989. "An Assessment of the Contingency Theory of Management Information Systems," Journal of Management Information Systems (6), pp. 59-85.

Wold, H. 1982. "Systems under Indirect Observation Using Pls," in A Second Generation of Multivariate Analysis, C. Fornell (ed.). New York: Praeger, pp. 325-347.

Yoon, S.J. 2002. "The Antecedents and Consequences of Trust in Online Purchase Decisions," Journal of Interactive Marketing (16:2), pp. 47-63.

Zhang, Y., Fang, Y., Wei, K.K., Ramsey, E., McCole, P. and Chen, H. 2011. "Repurchase intention in B2C e-commerce - a relationship quality perspective”, Information \& Management, 48, $192-200$

Zucker, L.G. 1986. "Production of Trust: Institutional Sources of Economic Structure: 1840-1920," in Research in Organizational Behavior, B.M. Staw and L.L. Cummings (eds.). Greenwich, CT: JAI Press, pp. 53-111. 


\section{Appendix I: Survey Questionnaire Items}

fraud, goods not received, etc.) of online shopping if something goes wrong with my online purchase.

I have confidence in third parties (e.g. SafeTrader, TRUSTe) to protect me

PEEIM2 against any potential risks (e.g. leaking of personal information, credit card fraud, goods not received, etc.) of online shopping if something goes wrong with my online purchase.

I am sure that I cannot be taken advantage of (e.g. leaking of personal

PEEIM3 information, credit card fraud, goods not received, etc.) as a result of conducting purchases online.

I believe that there are other parties (e.g. your credit card company) who have

PEEIM4 an obligation to protect me against any potential risks (leaking of personal

** information, credit card fraud, goods not received, etc.) of online shopping if something goes wrong with my online purchase.

Previous Satisfaction with Purchasing via the Internet (scale 1-7)

Please circle the number that best describes how satisfied you are with previous transactions via the Internet

New scale

developed

based on

definition,

recent

literature (e.g.,

Pavlou and

Gefen 2004),

and

preliminary

qualitative

interviews.

\begin{tabular}{|c|c|c|}
\hline & $\begin{array}{l}\text { Previous Satisfaction with Purchasing via the Internet (scale 1-7) } \\
\text { Please circle the number that best describes how satisfied you are with previous } \\
\text { transactions via the Internet }\end{array}$ & \multirow{4}{*}{$\begin{array}{l}\text { Based on } \\
\text { (Crosby and } \\
\text { Stevens 1987); } \\
\text { (Garbarino and } \\
\text { Johnson 1999); } \\
\text { and (Oliver } \\
\text { and Swan } \\
\text { 1989). }\end{array}$} \\
\hline SI1 & Overall, extremely satisfied. & \\
\hline SI2 & Overall, extremely pleased. & \\
\hline SI3 & My expectations were exceeded. & \\
\hline EXP1 & $\begin{array}{l}\text { Expertise in Using the Internet to Conduct Transaction (scale 1-7) } \\
\text { I know a lot about conducting purchases via the Internet. }\end{array}$ & \multirow{4}{*}{$\begin{array}{l}\text { Adapted from } \\
\text { (Jamal and } \\
\text { Naser 2002). }\end{array}$} \\
\hline EXP2 & I am experienced in conducting purchases via the Internet. & \\
\hline EXP3 & I am an expert buyer of products/services via the Internet. & \\
\hline EXP4 & I am informed about conducting purchases via the Internet. & \\
\hline & Questionnaire Items (Perceptions about a Specific Vendor) & Sources \\
\hline
\end{tabular}

As you fill out this part, PLEASE THINK OF A VENDOR YOU HAVE

PURCHASED FROM RECENTLY VIA THE INTERNET. A vendor could either be an organisation or company that produces or provides the product or service (e.g. www.easyjet.com; www.blackstar.co.uk), or it could be an intermediary that sells various products or services (e.g. www.tesco.com). It doesn't matter which one you choose, as long as you KEEP IT IN MIND as you fill out Part C.

So that you are clear, please answer the following preliminary questions before you proceed: The vendor I am thinking of (please tick the appropriate box):

[ ] is a company or brand that produces or provides the actual service, and the Web site address is http//www.

[ ] is an intermediary or wholesaler that sells a host of products and/or services on their Web site and the Web site address is http://www.

\section{Repurchasing Intention}

Please indicate the degree to which you agree with the following statements concerning your likelihood/probability of buying online again from the vendor you had in mind as you filled out this questionnaire 


\begin{tabular}{|c|c|c|}
\hline RPI1 & In the medium term? (1-Strongly disagree, 7- Strongly agree) & $\begin{array}{l}\text { Adapted/modif } \\
\text { ied from }\end{array}$ \\
\hline RPI2 & In the long term? (1-Strongly disagree, 7- Strongly agree) & \multirow{2}{*}{$\begin{array}{l}\text { ied from } \\
\text { Jarvenpaa et al. } \\
\text { (2000). }\end{array}$} \\
\hline RPI3 & $\begin{array}{l}\text { All things considered, and on a scale from } 1-100 \% \text {, what is the probability that } \\
\text { you will purchase online from the same vendor again? }\end{array}$ & \\
\hline & Trust in Vendor (scale 1-7) & \multirow{9}{*}{$\begin{array}{l}\text { Items adapted } \\
\text { and modified } \\
\text { from Einwiller } \\
(2003)^{*} \text {, } \\
\text { Jarvenpaa et al. } \\
\text { (2000), and } \\
\text { Garbarino and } \\
\text { Lee (2003). }\end{array}$} \\
\hline TV1 & I believe that this vendor is consistent in quality and service. & \\
\hline TV2 & I believe that this vendor is keen on fulfilling my needs and wants. & \\
\hline TV3 & I believe that this vendor is honest. & \\
\hline TV4 & $\begin{array}{l}\text { I believe that this vendor wants to be known as one that keeps promises and } \\
\text { commitments. }\end{array}$ & \\
\hline TV5 & I believe that this vendor has my best interests in mind. & \\
\hline TV6 & I believe that this vendor is trustworthy. & \\
\hline TV7 & I believe that this vendor has high integrity. & \\
\hline TV8 & I believe that this vendor is dependable. & \\
\hline & Previous Satisfaction with Vendor (scale 1-7) & \multirow{6}{*}{$\begin{array}{l}\text { Based on } \\
\text { (Crosby and } \\
\text { Stevens 1987); } \\
\text { (Garbarino and } \\
\text { Johnson 1999); } \\
\text { and (Oliver } \\
\text { and Swan } \\
\text { 1989). }\end{array}$} \\
\hline & Please circle the number that best describes how satisfied you are with previous & \\
\hline SV1 & Overall, extremely satisfied. & \\
\hline SV2 & Overall, extremely pleased. & \\
\hline SV3 & My expectations were exceeded. & \\
\hline SV4 & I would recommend this vendor to a friend. & \\
\hline & Vendor Image/Reputation (1-7 semantic differential) & \multirow{4}{*}{$\begin{array}{l}\text { From (Spencer } \\
\text { 1999) }\end{array}$} \\
\hline & $\begin{array}{l}\text { Please circle the number that best describes your perception of the vendor you } \\
\text { now have in mind on each of the attributes below }\end{array}$ & \\
\hline VR1 & Excellent public image & \\
\hline VR2 & Has an excellent reputation & \\
\hline & Perceived Website Quality (1-7 semantic differential) & \multirow{15}{*}{$\begin{array}{l}\text { Items adapted } \\
\text { from Balabanis } \\
\text { \& Reynolds } \\
\text { (2001); } \\
\text { Chakraborty et } \\
\text { al (2002), } \\
\text { Yoon (2002) }\end{array}$} \\
\hline & $\begin{array}{l}\text { Please circle the number that best describes your perception of the vendor's } \\
\text { website on each of the attributes below }\end{array}$ & \\
\hline PWQ1 & Extremely easy to use & \\
\hline PWQ2 & Extremely well organized & \\
\hline PWQ3 & Extremely easy to navigate & \\
\hline PWQ4 & Extremely easy to find information that I want & \\
\hline PWQ5 & Extremely easy to conduct online shopping & \\
\hline PWQ6 & Extremely fast in transmitting words and images & \\
\hline PWQ7 & Excellent in terms of operational efficiency (i.e. working links, etc) & \\
\hline PWQ8 & Extremely useful search/help functions & \\
\hline PWQ9 & Extremely interesting & \\
\hline PWQ10 & Extremely exciting & \\
\hline PWQ11 & Extremely entertaining & \\
\hline PWQ12 & Extremely clear layout & \\
\hline PWQ13 & High attention-grabbing ability & \\
\hline
\end{tabular}

Familiarity with vendor (scale 1-7)

Overall, how familiar are you with the vendor you now have in mind?

Product Characteristics

Price - Approximately how much did the product or service you bought cost (£ Sterling)?

Type- What was the item you bought? (coded as goods or service) 
* Items are taken from Einwiller's “vendor trust” scale. Einwiller sourced items for this scale from Doney and Cannon (1997), Kennedy et al. (2001), and Oswald and Fuchs (1998) and by considering the results of McKnight and Chervany's (2002a) meta analysis of trust definitions (see Einwiller 2003, p.208).

**: Removed from the further analysis due to low loadings 


\section{Appendix-II: Step-wise PLS Results Details}

\begin{tabular}{|c|c|c|c|c|c|c|}
\hline \multirow[t]{2}{*}{ Variables } & \multicolumn{3}{|c|}{ Trust in Vendor } & \multicolumn{3}{|c|}{ Repurchase Intention } \\
\hline & Model 1 & Model 2 & Model 3 & Model 1 & Model 2 & Model 3 \\
\hline \multicolumn{7}{|l|}{ Control Variables } \\
\hline Website Quality & $0.35^{* * *}$ & $0.33^{* * *}$ & $0.31^{* * *}$ & $0.34^{* * *}$ & $0.22^{* * *}$ & $0.22^{* * *}$ \\
\hline Reputation & $0.34^{* * *}$ & $0.31^{* * *}$ & $0.31^{* * *}$ & 0.08 & -0.09 & -0.09 \\
\hline Familiarity with the Vendor & 0.06 & 0.06 & 0.03 & 0.09 & 0.06 & 0.06 \\
\hline Satisfaction (Internet) & $0.10^{*}$ & 0.07 & 0.04 & $0.16^{* *}$ & 0.05 & 0.04 \\
\hline Gender & --- & --- & --- & 0.04 & -0.01 & -0.01 \\
\hline Income & --- & --- & --- & 0.00 & 0.00 & 0.00 \\
\hline Education & --- & --- & --- & 0.07 & 0.08 & 0.08 \\
\hline Expertise & --- & --- & --- & -0.01 & -0.01 & -0.01 \\
\hline \multicolumn{7}{|l|}{ Product Characteristics } \\
\hline Product type & --- & --- & --- & 0.06 & 0.08 & 0.08 \\
\hline Product price & --- & --- & --- & 0.06 & 0.06 & 0.06 \\
\hline PEEIM & 0.05 & 0.04 & 0.04 & 0.03 & 0.02 & 0.02 \\
\hline \multicolumn{7}{|l|}{ Independent Variables } \\
\hline Satisfaction with Vendor & & 0.09 & $0.151^{*}$ & 0.11 & $0.23^{* *}$ & $0.24^{* *}$ \\
\hline Trust in Vendor & & & & & $0.28^{* * *}$ & $0.26^{* * *}$ \\
\hline \multicolumn{7}{|l|}{ Interaction Effects } \\
\hline $\begin{array}{l}\text { Satisfaction with Vendor X } \\
\text { PEEIM }\end{array}$ & & & $0.17^{* * *}$ & & & \\
\hline Trust in Vendor X PEEIM & & & & & & $-0.12^{*}$ \\
\hline $\mathrm{R}^{2}$ & $45.17 \%$ & $45.70 \%$ & $48.4 \%$ & $28.91 \%$ & $36.40 \%$ & $37.97 \%$ \\
\hline$\Delta \mathrm{R} 2$ & --- & $0.53 \%$ & $2.7 \%$ & --- & $7.49 \%$ & $1.57 \%$ \\
\hline F(p-value) & & $3.48(0.063)$ & $\begin{array}{l}18.58^{*} \\
(<0.05)\end{array}$ & & $\begin{array}{l}20.61 * \\
(<0.05)\end{array}$ & $\begin{array}{l}8.83^{*} \\
(<0.05)\end{array}$ \\
\hline Effect Size $\left(\mathrm{f}^{2}\right)$ & & 0.01 & 0.05 & & 0.12 & 0.03 \\
\hline
\end{tabular}

Note: $* p<.05, * * p<.01, * * * p<.001$ (one-tailed test for the hypothesized interaction effects); 


\section{Appendix III: 3-D Plots for Interactions}

a) Interaction plot for Repurchase Intention

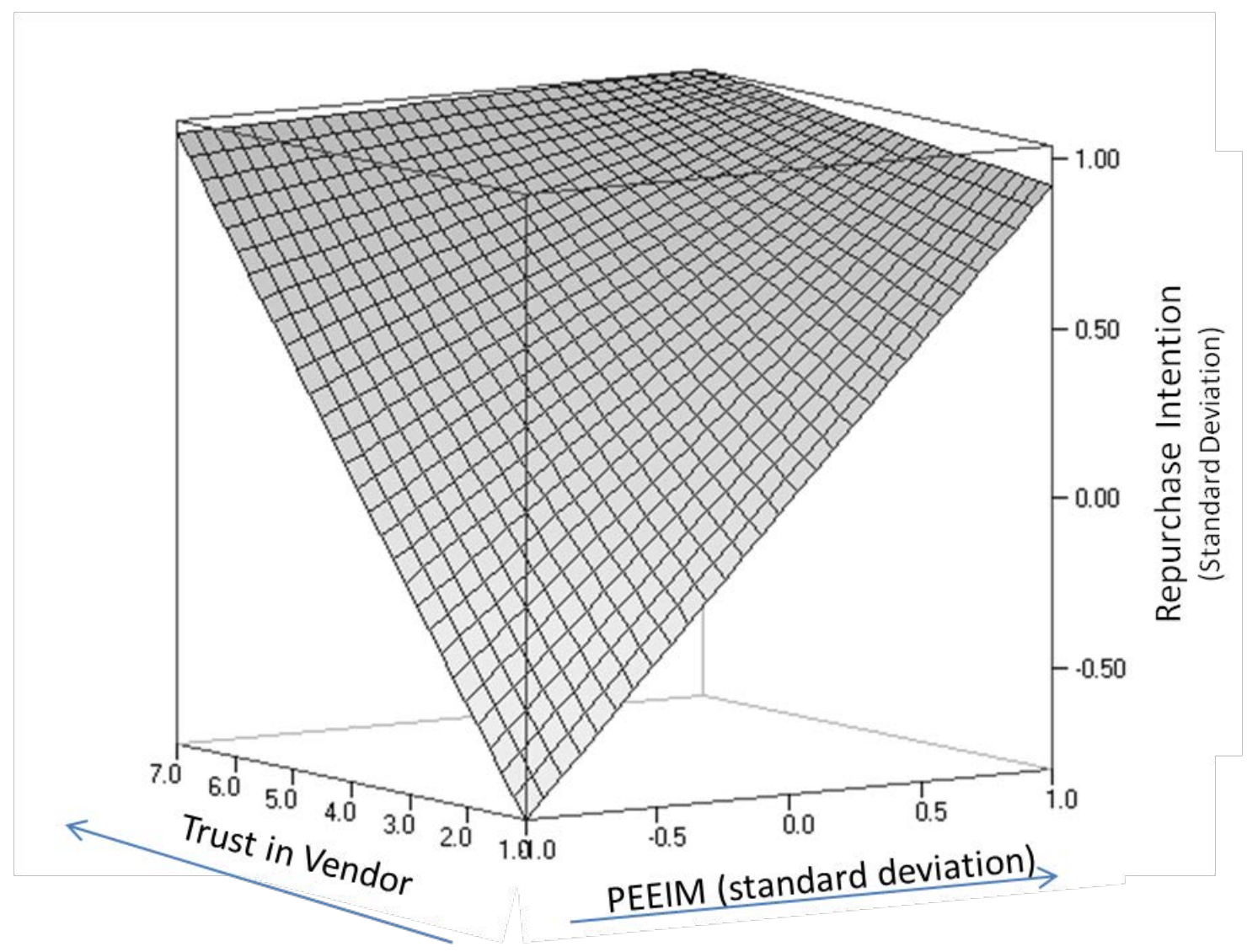




\section{b) Interaction plot for Trust in Vendor}

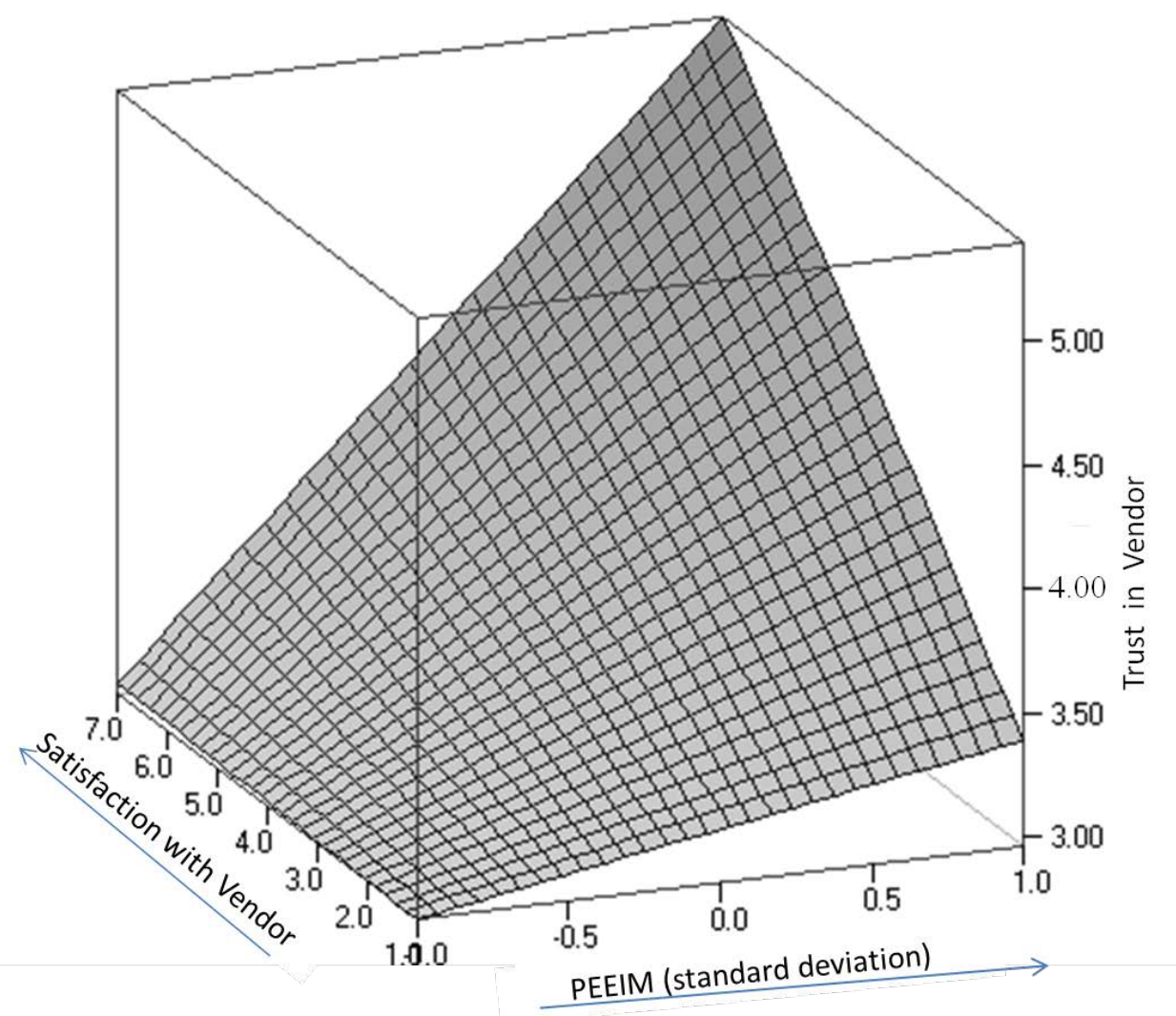




\section{Appendix IV - Discriminant Validity between Structural Assurances and PEEIM}

\section{(1) PEEIM with the original four indicators}

Initial evidence of convergent and discriminant validity was obtained from pattern of loadings and cross-loadings (Table A1). Most of the items appear to load well on their respective constructs and had loading greater than 0.8, well above minimal standard of 0.70 (Nunnally and Bernstein, 1994), providing evidence of convergent validity. PEEIM4 was the only exception with a loading of 0.60. Moreover, each item loaded poorly on the non-respective construct. The highest such cross-loading was 0.40 for PEEIM3. This provided initial empirical evidence of discriminant validity.

\begin{tabular}{|l|l|l|}
\hline \multicolumn{3}{|c|}{ Table A1: Loadings and Cross-Loadings } \\
\hline Items & SA & PEEIM \\
\hline SA1 & .77 & .36 \\
\hline SA2 & .93 & .28 \\
\hline SA3 & .89 & .36 \\
\hline SA4 & .83 & .25 \\
\hline PEEIM1 & .33 & .92 \\
\hline PEEIM2 & .34 & .84 \\
\hline PEEIM3 & .40 & .94 \\
\hline PEEIM4 & .13 & .60 \\
\hline
\end{tabular}

Next we calculated internal consistency reliability (ICR), average variance explained (AVE), and correlation between SA and PEEIM (Table A2). ICR for SA and PEEIM were 0.97 and 0.96 respectively suggesting a good internal consistency. To evaluate the discriminant validity we compared inter-construct correlation $(\gamma=0.57)$ with the square root of AVE, which is a measure of percentage of overall variance in the indicators captured by the latent construct (Hair et al. 1998). This comparison supports discriminant validity as the square root of AVE for each construct exceeds the correlation between them.

\begin{tabular}{|l|c|c|c|}
\hline \multicolumn{4}{|c|}{ Table A2: ICR, Square Root of AVE and Correlation } \\
\hline Constructs & ICR & SA & PEEIM \\
\hline SA & 0.97 & $\mathbf{. 8 6}^{\text {a }}$ & \\
\hline PEEIM & 0.96 & $.57^{\text {b }}$ & $\mathbf{. 8 4}$ \\
\hline Notes: \\
ICR - Internal Consistency Reliability \\
SA - Structural Assurances \\
PEEIM - Perceived Effectiveness of E-commerce Institutional Mechanisms \\
a Square-root of average variance extracted (AVE) is presented as bold-face numbers \\
b Correlation between latent constructs \\
\hline
\end{tabular}

Finally, we used nested model comparison (chi-square difference test) to further establish discriminant validity between the two constructs. This test involves comparing chi-square statistics obtained from two models: (A) correlation between SA and PEEIM unconstrained, and (B) correlation between SA and PEEIM constrained (to 1.0). If there is no significant difference between $\chi^{2}$ values of these two models then there is no discriminant validity, whereas if $\chi^{2}$ values are significantly different then two 
construct are statistically distinguishable (distinct) and reflected by their respective indicators (Anderson et al. 1988; Joreskog 1993).

The unconstrained model (i.e. where correlation was freely estimated) resulted in a $\chi 2$ value of 27.11 $(\mathrm{df}=20, \mathrm{p}=0.13)$. The constrained model (correlation $=1)$ yielded a $\chi 2$ value of $239.94(\mathrm{df}=21, \mathrm{p}=0.00)$. As the difference $(\Delta \chi 2=212.83, \mathrm{df}=1, \mathrm{p}=0.00)$ was much greater than the critical chi-square of 3.84 $(\mathrm{df}=1, \alpha=0.05)$, discriminant validity for the two constructs was supported.

\section{(2) PEEIM with the final three indicators}

As one of the item for PEEIM (PEEIM4) was loaded poorly (loading=0.6), and was not used in main study, we decided to re-test discrimnant validity without this item. Table A3 presents internal consistency reliability (ICR), square root of average variance explained (AVE), and correlation between SA and PEEIM (with the final three indicators). ICR for PEEIM was 0.83, suggesting a good internal consistency. To evaluate the discriminant validity we compared inter-construct correlation $(\gamma=0.59)$ with the square root of AVE of each construct. This comparison supports discriminant validity as the square root of the AVE for each construct exceeds the correlation between them.

\begin{tabular}{|l|c|c|c|}
\hline \multicolumn{4}{|c|}{ Table A3: ICR, Square Root of AVE and Correlation } \\
\hline Constructs & ICR & SA & PEEIM \\
\hline SA & 0.97 & $\mathbf{. 8 6}^{\mathrm{a}}$ & $\mathbf{. 7 9}$ \\
\hline PEEIM & 0.83 & $.59^{\mathrm{b}}$ & \\
\hline Notes: & \\
ICR - Internal Consistency Reliability \\
SA - Structural Assurances \\
PEEIM - Perceived Effectiveness of E-commerce Institutional Mechanisms \\
a Square-root of average variance extracted (AVE) is presented as bold-face numbers \\
b Correlation between latent constructs \\
\hline
\end{tabular}

Finally, we used nested model comparison (chi-square difference test) to further establish discriminant validity. The unconstrained model (i.e. where correlation was freely estimated) resulted in a $\chi^{2}$ value of $17.76(\mathrm{df}=13, \mathrm{p}=0.17)$, whereas the constrained model (correlation=1) yielded a $\chi^{2}$ value of 235.40 $(\mathrm{df}=14, \mathrm{p}=0.00)$. As the difference $\left(\Delta \chi^{2}=217.65, \mathrm{df}=1, \mathrm{p}=0.00\right)$ was greater than the critical chi-square of $3.84(\mathrm{df}=1, \alpha=0.05)$, discriminant validity for the two constructs was supported. 